\title{
Naphthoquinones and Their Derivatives: Emerging Trends in Combating Microbial Pathogens
}

\author{
Nishigandha S. Mone ${ }^{1}$, Srushti A. Bhagwat ${ }^{1}$, Deepansh Sharma ${ }^{2}\left(\mathbb{D}\right.$, Manohar Chaskar ${ }^{3}$, Rajendra H. Patil ${ }^{4} \mathbb{D}$, \\ Paolo Zamboni ${ }^{5}$, Neelu N. Nawani ${ }^{6, * \mathbb{D}}$ and Surekha K. Satpute ${ }^{1, * \mathbb{D}}$ \\ 1 Department of Microbiology, Savitribai Phule Pune University, Pune 411007, India; \\ nishigandhamone@gmail.com (N.S.M.); srushtibhagwat1998@gmail.com (S.A.B.) \\ 2 Amity Institute of Microbial Technology, Amity University, Rajasthan 303002, India; \\ deepanshsharma@gmail.com \\ 3 Department of Chemistry, Prof. Ramkrishna More College of Arts, Commerce \& Science, Pune 411044, India; \\ manohar_c@hotmail.com \\ 4 Department of Biotechnology, Savitribai Phule Pune University, Pune 411007, India; rpati@unipune.ac.in \\ 5 Vascular Diseases Center, Azienda Ospedaliera Universitaria di Ferrara via Aldo Moro 8, 44124 Ferrara, Italy; \\ zambo@unife.it \\ 6 Microbial Diversity Research Centre, Dr. D. Y. Patil Biotechnology \& Bioinformatics Institute, \\ Dr. D. Y. Patil Vidyapeeth, Pune 411033, India \\ * Correspondence: neelu.nawani@dpu.edu.in (N.N.N.); satputesk@unipune.ac.in or \\ drsurekhasatpute@gmail.com (S.K.S.); Tel.: +91-02067919444 (N.N.N.); +91-02025690643 (S.K.S.)
}

Citation: Mone, N.S.; Bhagwat, S.A.; Sharma, D.; Chaskar, M.; Patil, R.H.; Zamboni, P.; Nawani, N.N.; Satpute, S.K. Naphthoquinones and Their Derivatives: Emerging Trends in Combating Microbial Pathogens. Coatings 2021, 11, 434. https:// doi.org/10.3390/coatings11040434

Received: 6 March 2021

Accepted: 6 April 2021

Published: 9 April 2021

Publisher's Note: MDPI stays neutral with regard to jurisdictional claims in published maps and institutional affiliations.

Copyright: (c) 2021 by the authors. Licensee MDPI, Basel, Switzerland. This article is an open access article distributed under the terms and conditions of the Creative Commons Attribution (CC BY) license (https:// creativecommons.org/licenses/by/ $4.0 /)$.

\begin{abstract}
In the current era, an ever-emerging threat of multidrug-resistant (MDR) pathogens pose serious health challenges to mankind. Researchers are uninterruptedly putting their efforts to design and develop alternative, innovative strategies to tackle the antibiotic resistance displayed by varied pathogens. Among several naturally derived and chemically synthesized compounds, quinones have achieved a distinct position to defeat microbial pathogens. This review unleashes the structural diversity and promising biological activities of naphthoquinones (NQs) and their derivatives documented in the past two decades. Further, realizing their functional potentialities, researchers were encouraged to approach NQs as lead molecules. We have retrieved information that is dedicated on biological applications (antibacterial, antifungal, antiparasitic) of NQs. The multiple roles of NQs offer them a promising armory to combat microbial pathogens including MDR and the ESKAPE (Enterococcus faecium, Staphylococcus aureus, Klebsiella pneumoniae, Acinetobacter baumannii, Pseudomonas aeruginosa, and Enterobacter spp.) group. In bacteria, NQs may exhibit their function in the following ways (1) plasmid curing, (2) inhibiting efflux pumps (EPs), (3) generating reactive oxygen species (ROS), (4) the inhibition of topoisomerase activity. Sparse but meticulous literature suggests the mechanistic roles of NQs. We have highlighted the possible mechanisms of NQs and how the targeted drug synthesis can be achieved via molecular docking analysis. This bioinformaticsoriented approach will explicitly lead to the development of effective and most potent drugs against targeted pathogens. The mechanistic approaches of emerging molecules like NQs might prove a milestone to defeat the battle against microbial pathogens.
\end{abstract}

Keywords: efflux pumps; MDR; ESKAPE pathogens; naphthoquinones; plasmid curing; reactive oxygen species; topoisomerase

\section{Introduction}

Antibiotics represent world-class, assured molecules that have captured a gigantic share in the global market to combat ever-rising and prevalent infections. Over decades, different types of antibiotics have come into medical practice. Penicillin occupied the European and U.S. markets since its discovery in 1928 by Sir Alexander Fleming, followed by its commercial production in the 1940s [1]. Further, the world was gifted with the discovery of another antibiotic, streptomycin, by Albert Schatz, Bugie, and Waksman in 
1943. This antibiotic was able to inhibit bacteria, predominantly the organisms responsible for tuberculosis [2]. After the success stories of penicillin and streptomycin, a huge number of antibiotics succeeded commercially, such that the projected rise of the global antibiotic market is up to US $\$ 67.25$ billion by 2026 [3].

The challenges of resistance acquired by microbial pathogens towards existing antibiotics led to the advent of new antimicrobials. Presently, healthcare sectors are severely affected due to eternally escalating antimicrobial resistance (AMR) shown by pathogenic bacteria, parasites, viruses, and fungi. This serious threat associated with public health needs urgent attention and an immediate action plan from government policymakers, as well as private industries. It is essential to note that the challenges associated with AMR have led to a substantial cost escalation for pharmaceutical and health-care products. Patients suffering from microbial infections are ultimately the victims of long-term illness, and are therefore loaded with an additional monetary burden in the form of expensive tests and drugs $[4,5]$. There is also an increased morbidity and mortality rate in patients. These multidrug-resistant (MDR) pathogens are therefore referred to as " $\mathrm{Su}$ per Bugs" [6]. MDR bacterial pathogens also comprise the ESKAPE group [7]. The abbreviation 'ESKAPE' has been used to designate a group having Enterococcus faecium, Staphylococcus aureus, Klebsiella pneumoniae, Acinetobacter baumannii, Pseudomonas aeruginosa, and Enterobacter spp. In the year 2008, Rice [8] had coined the terminology 'the ESKAPE bugs' to denote the ability of pathogens to escape from the lethal activity of antibiotics and impose severe menace to human health. These pathogens exhibit resistance to antimicrobial drugs like carbapenems, fluoroquinolones, glycopeptides, $\beta$-lactams, $\beta$-lactam- $\beta$-lactamase inhibitor combinations, lipopeptides, macrolides, tetracyclines, and polymyxins etc. [7]. In the year 2017, the World Health Organization (WHO) published a list of priority pathogens -Priority 1 (Critical), Priority 2 (High) and Priority 3 (Medium) — exhibiting resistance to antimicrobial agents [9]. These pathogens can worsen emergency situations and therefore, need urgent surveillance so that new and more effective compounds can be brought through the pipelines. Since 2015, WHO has introduced World Antibiotic Awareness Week (WAAW) to create awareness in the public community, health workforce and among policy-formulating personnel to restrict further emergence of antibiotic resistance and its spread. Since 2020, the Tripartite Executive Committee declared WAAW dates to be 18-24 November [10].

To gain AMR, pathogens acquire plasmids (R-drug resistance) or transposons and also possess multidrug efflux pumps (EPs) to drive out the drug molecules from their system [11]. Besides, other strategies are used, like (1) inactivation, alteration, or degradation of the drug by bacterial enzymes, (2) modification of drug binding sites on the bacterial cell, (3) biofilm formation (restricting the entry of the drug), and (4) reduction in intracellular drug accumulation [12]. Challenges associated with AMR encouraged researchers to explore a variety of naturally existing and chemically synthesized compounds over the decades. Since ancient times, medicinal plants have been evidenced as a great support to tackle dreaded illnesses [13]. Recent advances in the area of phytochemicals and synthesized derivatives have been looked forward to due to their multifunctional therapeutic approaches for dealing with AMR-associated challenges [14-17]. The unique structural, biological, and functional properties of naphthoquinones (NQs), along with their derivatives, have gained enormous consideration, particularly from a medicinal chemistry perspective [18]. NQs are widely distributed as natural pigments in plants, fungi, and some animals [19]. NQ derivatives bearing hydroxyl, methyl, nitrogen, sulfur, halide, phenylamino-phenylthio, or sulphide possess exceptional biological activity. Derivatives bearing hydroxyl groups are seeking more consideration due to their broad-spectrum pharmacological properties [20]. NQs possess widespread antibacterial, antiparasitic [21,22], antifungal, [23,24], antiviral [25], and antimalarial properties [26]. In the field of cancer biology, NQs are also noticeably identified for their abilities to produce reactive oxygen species (ROS) in cancer cell lines [27-29]. NQs are propitious candidates over the other chemotherapeutic drugs used currently. Until today, an ample number of NQ derivatives have been 
analyzed for their functional potential against various pathogens. This encouraged us to present a comprehensive review of the structural diversity and multifunctional potentiality of NQs in medicinal chemistry. We also shed a light on the current understanding of the mechanistic roles of NQs in combating microbial infections. We also emphasize molecular docking - a powerful approach used in predicting the interactions of NQ molecules in biological systems.

\section{Structural Diversity of Naphthoquinones Entities}

Structurally, NQs constitute bicyclic structures with two carbonyl groups placed either in positions 1,4 or 1,2. The latter case is less frequent (Figure 1A). The chemistry and biological activities of quinones are primarily dependent on the position and chemical nature of the side groups attached (R). Groups like hydrogen, hydroxyl, methyl, nitrogen, sulfur, halide, etc. are attached to the NQ's ring structure. Generally, the presence of a hydroxyl and/or methyl group in quinone structure is found in nature. These derivatives have been reported for a broad range of applications in pharmacology [19]. Recently, NQ derivatives isolated from plant sources including lawsone, juglone, plumbagin, shikonin and lapachol (Table 1) have fascinated researchers due to their (1) abundance, (2) structural diversity, and (3) broad-spectrum therapeutic potential [20]. It is imperative to state that 1,4-NQs derivatized at the 2nd and 3rd position with different chemical groups are recurrently reported for their biological properties (Table 1 ). NQs having oxygen entities at 1, 4 positions in the aromatic ring exhibit promising antimicrobial properties. Sparse literature is evident on 1,2-NQs. Realizing the significance of 1,4-NQ derivatives for biological applications, the major focus of this review remains on 1,4-NQ derivatives.

Table 1. Chemical structures of plant-originated naphthoquinone derivatives.

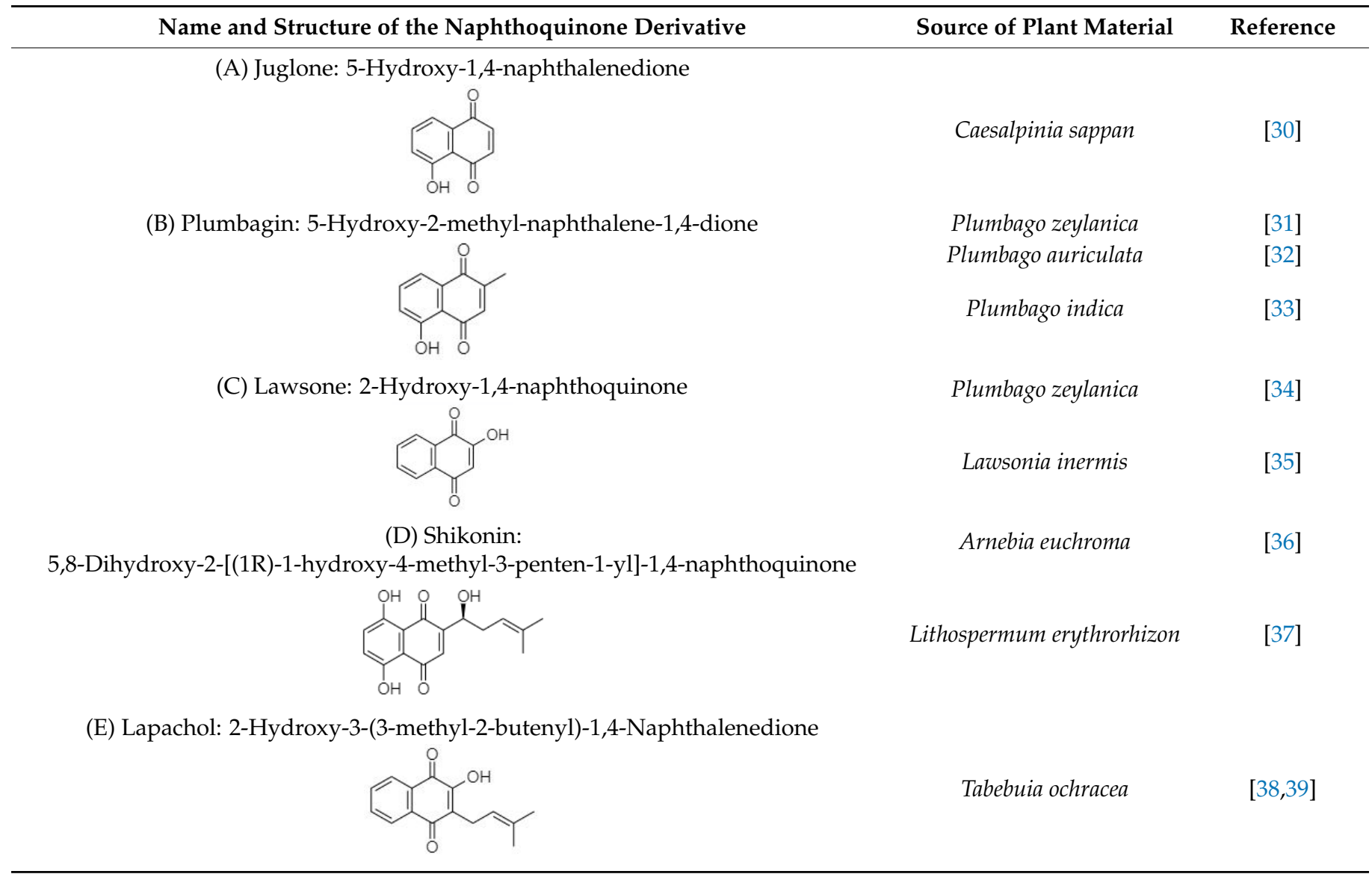


A Widely explored 1,4-Naphthoquinones and their derivatives for biological activity<smiles>O=C1C=CC(=O)c2ccccc21</smiles>

1, 4 - Naphthoquinone (Antibacterial, Antifungal, Antiparasitic, Antiparasitic etc.)

$2,3,5$ and 8 positions in 1, 4- Naphthoquinone are preferred to synthesize various derivatives

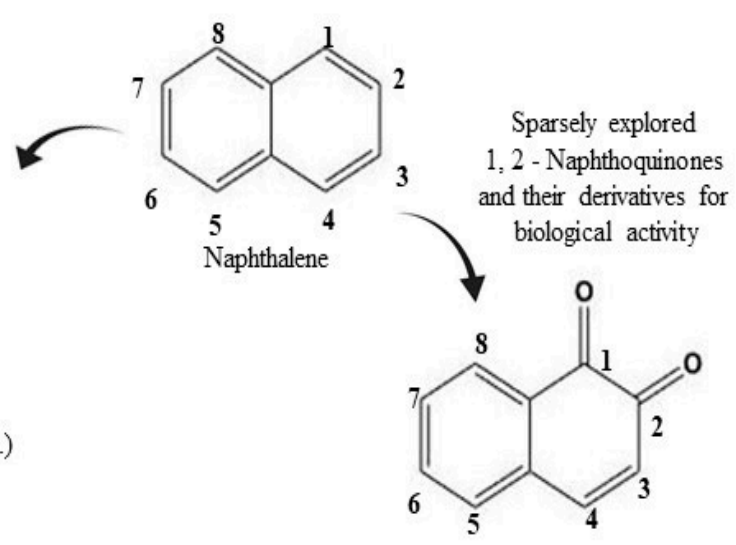

1,2 - Naphthoquinone

\section{B}

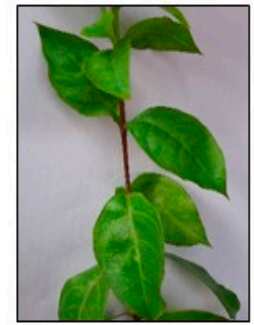

Collection of plant material (Root, leaves, stem etc.)

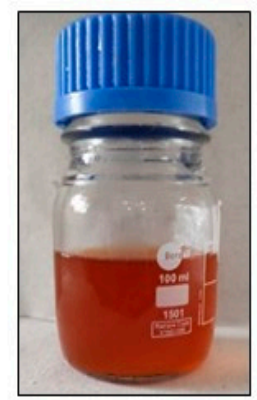

Collection and concentration of crude extract

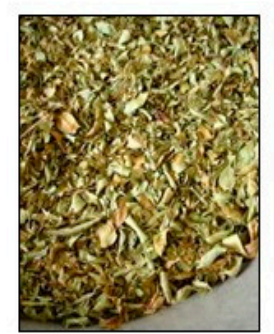

Air drying of the plant material

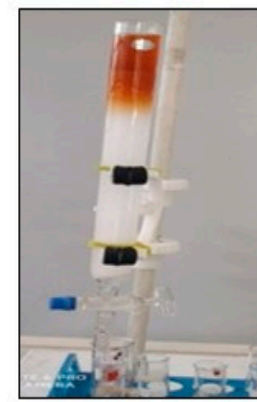

Purification by column chromatography

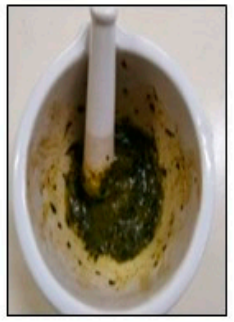

Preparation of paste in Buffer

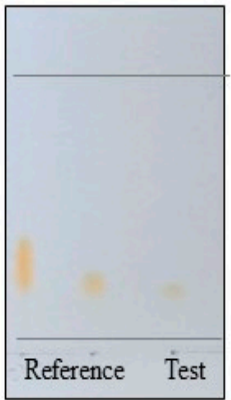

Preliminary

Detection by TLC

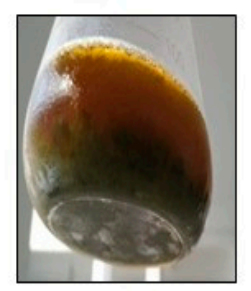

Overnight soaking

Analytical Characterization TLC, FTIR, NMR, MS, HPLC etc.
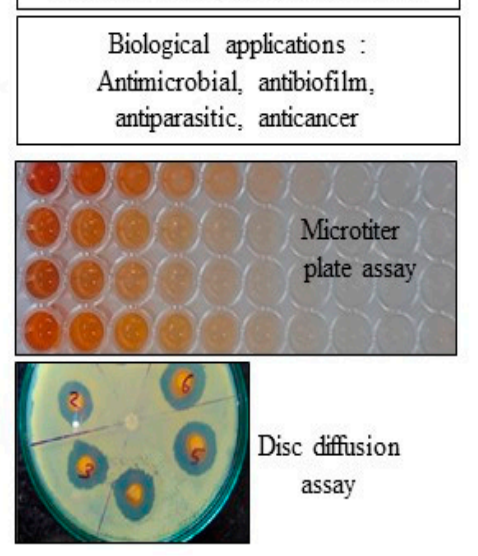

Figure 1. Diversity of naphthoquinone molecules. (A): structures of chemically synthesized naphthoquinones. (B): production, purification, characterization, and biological applications of 1,4-naphthoquinone derivatives from plant material. 


\section{1,4-Naphthoquinone Derivatives}

The 1,4-NQs are redox-active compounds having resemblance to the structure of naphthalene [40]. Researchers have focused on 1,4-NQ derivatives to explore for antibacterial, antifungal, antiviral, anticancer, and antiparasitic potential. The following sections describe 1,4-NQs, both natural-origin and chemically synthesized, having immense antimicrobial potential against various pathogens, including those that are MDR or in the ESKAPE category.

\subsection{1,4-Naphthoquinone Derivatives of Natural Origin}

Naphthoquinones, phenol-rich compounds, are seen abundantly in a variety of plants [30,32], animals [41], and fungi [42]. The functional potency of any antimicrobial agent is uniquely determined from its minimum inhibitory concentration (MIC). The MIC represents the lowest concentration that hampers the visible growth of microbes. Minimum bactericidal concentrations (MBCs) indicate the lowest concentration of a compound that prevents the growth of an organism by killing it. Therefore, MICs and MBCs are imperative for any antimicrobial agent to be considered for pharmacological applications. MICs of plant-derived NQs against pathogenic bacteria are represented in Table 2.

Table 2. Naphthoquinones extracted from plants along with their minimum inhibitory concentration (MIC).

\begin{tabular}{|c|c|c|c|}
\hline Type of Naphthoquinone & Active against Bacterial Strains & $\operatorname{MIC}(\mu \mathrm{g} / \mathrm{mL})$ & Reference \\
\hline \multirow{5}{*}{ Shikonin from Arnebia euchroma root extract } & Staphylococcus aureus & 128 & \multirow{5}{*}[36]{} \\
\hline & Streptococcus agalactiae & 128 & \\
\hline & Escherichia coli & 256 & \\
\hline & Salmonella isolates & 256 & \\
\hline & Pseudomonas aeruginosa & 512 & \\
\hline \multirow{4}{*}{ Plumbagin from Plumbago zeylanica } & Staphylococcus aureus & 0.5 & \multirow{4}{*}[43]{} \\
\hline & Escherichia coli & 8 & \\
\hline & Klebsiella pneumoniae & 2 & \\
\hline & Pseudomonas aeruginosa & 8 & \\
\hline Plumbagin from Plumbago zeylanica & S. aureus (MRSA) & $4-8$ & [31] \\
\hline \multirow{12}{*}{ Lawsone from Plumbago zeylanica root extract } & Staphylococcus aureus & 400 & \multirow{12}{*}[34]{} \\
\hline & Salmonella typhi & 200 & \\
\hline & Bacillus cereus & 200 & \\
\hline & Bacillus subtilis & 200 & \\
\hline & Pseudomonas aeruginosa & 800 & \\
\hline & Escherichia coli & 800 & \\
\hline & Shigella dysenteriae & 400 & \\
\hline & Serratia marcescens & $>1600$ & \\
\hline & Proteus mirabilis & $>1600$ & \\
\hline & Klebsiellapneumoniae & 800 & \\
\hline & Enterobacter & 800 & \\
\hline & Acinetobacter baumannii & 800 & \\
\hline \multirow{11}{*}{ Naphthoquinone pigments from Onosma visianii } & Bacillus megaterium & $9.54-54.28$ & \multirow{11}{*}[44]{} \\
\hline & Montrichardia arborescens & $6.82-54.28$ & \\
\hline & Micrococcus luteus & $9.54-76.20$ & \\
\hline & Staphylococcus epidermidis & $9.54-54.28$ & \\
\hline & Enterococcus faecalis & $6.82-38.10$ & \\
\hline & Citrobacter koseri & $6.82-76.20$ & \\
\hline & Hafnia alvei & $6.82-54.28$ & \\
\hline & Pseudomonas proteolytica & $4.77-76.20$ & \\
\hline & Stenotrophomonas maltophilia & $4.77-76.20$ & \\
\hline & Yersinia intermedia & $6.82-76.20$ & \\
\hline & - & (values depict $\mathrm{MIC}_{90}$ ) & \\
\hline \multirow{2}{*}{ Shikonin from Lithospermum erythrorhizon } & Staphylococcus aureus (MRSA) & $7.8-31.2$ & \multirow{2}{*}{ [37] } \\
\hline & Staphylococcus aureus (MSSA) & 7.8 & \\
\hline \multirow{4}{*}{ Plumbago auriculata root extracts } & Proteus vulgaris & Strong activity & \multirow{4}{*}{ [32] } \\
\hline & Klebsiella. pneumoniae & Strong activity & \\
\hline & Escherichia coli & Moderate activity & \\
\hline & Pseudomonas aeruginosa & Less activity & \\
\hline
\end{tabular}


Table 2. Cont.

\begin{tabular}{|c|c|c|c|}
\hline Type of Naphthoquinone & Active against Bacterial Strains & $\operatorname{MIC}(\mu \mathrm{g} / \mathrm{mL})$ & Reference \\
\hline Naphthoquinone from Alkanna orientalis extracts & $\begin{array}{c}\text { Bacillus megaterium } \\
\text { Bacillus mesentericus } \\
\text { Bacillus mycoides } \\
\text { Bacillus subtilis } \\
\text { Brevibacterium flavum } \\
\text { Enterococcus hirae } \\
\text { Micrococcus luteus } \\
\text { Staphylococcus aureus } \\
\text { Staphylococcus citreus } \\
\text { Staphylococcus roseus } \\
\text { Escherichia. coli } \\
\text { Salmonella typhimurium }\end{array}$ & $\begin{array}{l}125 \\
125 \\
125 \\
125 \\
250 \\
250 \\
250 \\
125 \\
500 \\
125 \\
500 \\
750\end{array}$ & [45] \\
\hline Lawsone from Lawsonia inermis & $\begin{array}{c}\text { Bacillus subtilis } \\
\text { Staphylococcus aureus } \\
\text { Escherichia coli } \\
\text { Pseudomonas aeruginosa }\end{array}$ & $\begin{array}{c}\text { Activity at } 1000 \mu \mathrm{g} / \text { disc } \\
\text { No activity } \\
\text { No activity } \\
\text { No activity }\end{array}$ & [35] \\
\hline Plumbago indica from root extracts & $\begin{array}{l}\text { Cutibacterium acnes (formerly } \\
\text { Propionibacterium acnes) } \\
\text { Staphylococcus aureus } \\
\text { Staphylococcus epidermidis }\end{array}$ & $\begin{array}{l}12.5 \\
12.5 \\
0.78\end{array}$ & [33] \\
\hline Naphthoquinones from Caesalpinia sappan & $\begin{array}{l}\text { Clostridium perfringens } \\
\text { Bacillus bifidum } \\
\text { Bacillus. breve } \\
\text { Lactobacillus casei } \\
\text { Escherichia coli }\end{array}$ & $\begin{array}{l}\text { Activity observed } \\
\text { Activity observed } \\
\text { No significant activity } \\
\text { Minute activity } \\
\text { Minute activity }\end{array}$ & [30] \\
\hline
\end{tabular}

This section is devoted to the structural diversity and functional potentiality of NQs of plant origin. Various plants, namely, Plumbago zeylanica, Plumbago indica, Lawsonia inermis, Plumbago auriculata, Caesalpinia sappan, Onosma visianii, and Impatiens glandulifera, and solvents like methanol, chloroform, acetone, ethanol, petroleum ether, diethyl ether, benzene, acetonitrile (ACN), dimethyl sulfoxide (DMSO), dimethylformamide (DMF), ethyl acetate (EA), isopropyl alcohol (IPA), and water etc. have been reported to extract NQs. Among those organic solvents, ethanolic and methanolic extracts appear to result in a relatively purer form of NQs with limited interfering compounds. The overall protocol used to produce, purify, and characterize 1,4-NQs from plant material is illustrated in Figure 1B. Juglone, plumbagin, lawsone, shikonin, and lapachol are a few examples of 1,4-NQs found profusely in nature and are also recognized for their substantial antimicrobial potential [46]. Lim et al. [30] extracted 5-hydroxy-1,4-naphthoquinone (juglone) (A in Table 1) from Caesalpinia sappan heartwood and examined its activity against intestinal cultures, viz. Bifidobacterium bifidum, Bifidobacterium breve, Clostridium perfringens, Escherichia coli, and Lactobacillus casei. Authors had purified those bioactive molecules using different solvents, like methanol, EA, butanol, chloroform, hexane, and water. The powerful growth-inhibition activity of NQ was obtained from EA, butanol, and methanol extracts against B. bifidum and C. perfringens. Chloroform fractions resulted in moderate antimicrobial activity, whereas water and hexane fractions were ineffective against both pathogens. The scenario presented here is quite interesting and justifies the selectivity and specificity of bioactive compounds isolated from C. sappan heartwood using different solvents. Authors also screened commercially accessible compounds like 5-hydroxy-1, 4-NQ, 5-hydroxy-2-methyl-1,4-NQ, 1,4-NQ, and 1,2-NQ against the above-mentioned test organisms at concentrations of $0.25,0.5,1,2$, and $5 \mathrm{mg} /$ disk. Their analysis recommended the dose-dependent activity of 1,4-NQ, and 1,2-NQ against $C$. perfringens, rather than other isolates used by them. Additionally, the 1,4-NQ derivative showed superior activity against four other organisms (B. bifidum, B. breve, E. coli, and L. casei) as compared to other derivatives (5-hydroxy-1,4-NQ and 5-hydroxy-2-methyl-1,4-NQ). Results also confirmed that the antibacterial activity of 1,4-NQ was reduced significantly due to the presence of a $-\mathrm{CH}_{3}$ group at the 2 nd and an $-\mathrm{OH}$ group at the 5 th position. 
Plumbagin (B in Table 1) is another widely explored secondary plant metabolite. Plumbagin is of immense interest due to its abilities to (1) generate ROS, (2) inhibit EPs, (3) accumulate drugs, and (4) cure plasmids from bacteria. Thus, due to such exceptional properties, it has been utilized as an effective antibacterial agent [47]. Periasamy et al. [31] evaluated the antibacterial activity of plumbagin (from Plumbago zeylanica) against 100 methicillin-resistant $S$. aureus (MRSA) strains, including MDR phenotypes. P. zeylanica root extract was obtained using ACN, DMSO, DMF, IPA, methanol and water. All fractions were used to analyze their antibacterial potential where active constituents of $\mathrm{ACN}$ and water showed the highest and lowest antibacterial activity respectively. Thus, Periasamy et al. [31] demonstrated that NQ constituents obtained using ACN possess promising and consistent antibacterial activity (at MIC of $4-8 \mu \mathrm{g} / \mathrm{mL}$ ) against MRSA strains.

Similarly, Adusei et al. [43] reported a bacteriostatic effect of plumbagin (P. zeylanica) extract using EA. The authors verified its antibacterial effect at $0.5,8,2$, and $8 \mu \mathrm{g} / \mathrm{mL}$ against S. aureus, E. coli, K. pneumoniae and P. aeruginosa respectively. This research group also assessed the resistance-modulating potential of antibiotics using plumbagin at its subinhibitory concentration of $4 \mu \mathrm{g} / \mathrm{mL}$. This assessment demonstrated a range of MICs for ciprofloxacin ( 0.25 to $2 \mu \mathrm{g} / \mathrm{mL})$, amoxicillin $(0.25$ to $256 \mu \mathrm{g} / \mathrm{mL})$, ampicillin ( 0.25 to $256 \mu \mathrm{g} / \mathrm{mL}$ ), and ketoconazole (no activity) against test pathogens. Their findings presented the successful resistance-modulating potential of three antibiotics, viz. ciprofloxacin, amoxicillin, and ampicillin, with plumbagin against S. aureus and E. coli. The activity of those three antibiotics was enhanced up to 2-fold when they were used in combination with plumbagin. Surprisingly, the enhancement of the 2-fold activity of ciprofloxacin was found against $P$. aeruginosa, whereas the activity of amoxicillin and ampicillin was reduced to 2-fold against the same isolate. For K. pneumoniae, the activity of amoxicillin and ampicillin was found to be enhanced up to 6-fold. At the same time, the efficiency of ciprofloxacin was reduced by 2 -fold for K. pneumoniae [43]. The synergistic approaches are unquestionably valuable to prove the potential of plumbagin as a favorable drug. Adusei et al. [43] further reported the considerable antibiofilm activity of plumbagin ( 32 to $128 \mu \mathrm{g} / \mathrm{mL}$ ) against the above-mentioned five pathogens. The antibiofilm activity of plumbagin was noticeably higher against $S$. aureus as compared to ciprofloxacin. Both plumbagin and ciprofloxacin displayed antibiofilm activity $(>50 \%)$ against the other three pathogens (S. aureus, E. coli, and K. pneumoniae) at $128 \mu \mathrm{g} / \mathrm{mL}$ concentration. The combination of plumbagin with other drugs undoubtedly impede the growth and infection of biofilm-forming pathogens.

The literature suggests that plumbago species has always been a choice NQ among the ones of natural sources. Patwardhan et al. [32] documented the effectiveness of P. auriculata root extract against 23 nosocomial pathogenic strains including P. aeruginosa, P. vulgaris, E. coli, and K. pneumoniae. Solvent extracts of plumbago roots were evaluated at various concentrations from 250 to $4000 \mu \mathrm{g} / \mathrm{mL}$. Plumbago extract obtained using ethanol displayed the highest antimicrobial activity as compared with other solvents. Ethanolic based extracts impeded the growth of P. vulgaris and K. pneumoniae, followed by E. coli. It is important to mention that $P$. aeruginosa was found to be the least affected with the same ethanolic plumbago extract.

A report documented by Kaewbumrung and Panichayupakaranant [33] explains the stability and the yield of plumbagin from $P$. indica roots. For the extraction procedure, authors used ethanol, EA, DCM, diethyl ether, and isopropanol. Out of those five solvents, ethanol was found to be the most suitable to result extract $(11.5 \% w / w)$ having a high amount $(5.79 \mathrm{mg} / \mathrm{g})$ of the plumbagin. Further purification and elution of pure plumbagin was achieved using a silica gel column with a mixture of hexane: EA $(9.2 \%: 0.8 \% v / v)$. This step enhanced the total plumbagin content $(13.26 \% w / w)$. Impurities soluble in hexane and EA were removed to result in a purified form of a derivative. The promising bactericidal activity of plumbagin extract was observed against $S$. aureus, S. epidermidis, and P. acnes. Like EA, petroleum ether has been the solvent of choice to extract NQs from plant sources. Vukic et al. [44] used petroleum ether along with EA to isolate NQs 
from Onosma visianii. Thus, the selection of appropriate solvents is important to obtain biologically active components from plant materials. From the above discussed literature, we underscore the pivotal role of solvents to extract NQs from natural sources. Attention to this concept could be helpful to enhance the overall yield of NQs from the desired biological sources. In conclusion, plumbago species are one of the preferred natural sources to isolate NQs. Among various solvents, ethanol is a virtuous choice for the extraction of bioactive compounds, followed by EA and hexane to demonstrate the assured biological activity of NQs.

Like plumbagin, another NQ—namely lawsone (C in Table 1) — has stimulated researchers to explore its medicinal potential. The foremost report on the extraction of lawsone (2-hydroxy-1,4-NQ) from P. zeylanica was accomplished by Patwardhan et al. [34]. Authors extracted lawsone via the solvents acetone, benzene, chloroform, cyclohexane, diethyl ether, ethanol, methanol, and petroleum ether. Consequently, Patwardhan and collaborators [34] focused on the biological activity, purification, and characterization of lawsone extracted using ethanol. The antibacterial potential of ethanolic root extract (ranging from 200 to $800 \mu \mathrm{g} / \mathrm{mL}$ ) was effective against three Gram-positive cultures (S. aureus, B. cereus, and B. subtilis) and six Gram-negative cultures (E. coli, S. typhi, Enterococcus spp., K. pneumoniae, A. baumannii, and S. dysenteriae). However, the same ethanolic extract was operative against $S$. marcescens and Proteus mirabilis at higher concentrations $(>1600 \mu \mathrm{g} / \mathrm{mL})$. Patwardhan et al. [34] also examined the plasmid-curing efficiency of lawsone, which is discussed briefly in Section 5.1.

A liposoluble red-colored pigment, shikonin (D in Table 1), is usually extracted from the roots of various plants like Alkanna tinctorial, Lithospermum erythrorhizon, or Arnebia decumbens L. Shikonin is one of the unique bioactive NQs routinely extracted from the roots of L. erythrorhizon, and is popular for several biological activities.

Lee et al. [37] isolated shikonin from the roots of L. erythrorhizon and examined its antibacterial potency against seven MRSA strains. This study revealed the MIC of shikonin to be 7.8 to $31.2 \mu \mathrm{g} / \mathrm{mL}$. MRSA strains were found to be more susceptible to shikonin, as compared to ampicillin and oxacillin (antibiotics of the penicillin class, cell wall attacking). Shikonin was evaluated in combination with Tris and Triton X-100 (membranepermeabilizing agents), sodium azide and $\mathrm{N}, \mathrm{N}^{\prime}$-dicyclohexylcarbodiimide (ATPase inhibitors), and peptidoglycan (derived from S. aureus). The work was supported through experiments like (1) the broth microdilution method (to analyze the susceptibility of bacteria to antibacterial agents), (2) the time-kill test (to determine the bactericidal/bacteriostatic activity of antibacterial agents over time), and (3) transmission electron microscopy (predicting the underlying mechanism of antibacterial agents affecting cell morphology). Studies have discovered the enhanced antibacterial activity of shikonin in the presence of Tris and Triton X-100 and ATPase inhibitors. Lee et al. [37] suggested that shikonin can be proposed as a natural antibiotic and even to realize the underlying mechanism responsible for antimicrobial action. Al-Mussawi [48] had also isolated shikonin from Arnebia decumbens L. and purified it using column chromatography. Researchers proved the antibacterial activity of shikonin against $P$. aeruginosa, E. coli, S. aureus, and K. pneumonia. Moreover, shikonin has been widely explored for anti-inflammatory, wound-healing, antithrombotic, and anticancer properties [49]. Large-scale production of any bioactive molecule is mandatory to utilize them for pharmacological purposes. When NQs are extracted from natural plant sources, the yield and purity cannot be neglected. Recently, Huang et al. [36] developed an ultrasound-assisted extraction (UAE) technique to isolate shikonin from A. euchroma. The response surface methodology (RSM) was used to design an appropriate extraction set-up for the production of shikonin. This experiment set-up can encourage researchers to extract shikonin at ease using an energy-saving approach. Authors magnificently reported around a $1.26 \%$ yield of shikonin under the ideal extraction protocol using ultrasound power at $93 \mathrm{~W}$ (in $87 \mathrm{~min}$ at $39^{\circ} \mathrm{C}$ ) with a liquid-solid ratio of 11:1. The same studies supplemented the antimicrobial activity of shikonin with clinical isolates (three) along with standard ones (five) at MICs of 128-1024 $\mu \mathrm{g} / \mathrm{mL}$. Extracts obtained from the medicinal plants find 
applications in the manufacturing of ointment to treat patients with burn infections. Aljanaby [50] isolated an aqueous extract having alkannin esters and shikonin from $A$. tinctoria and demonstrated antibacterial activity against drug-resistant bacterial strains (395) at a $300 \mathrm{mg} / \mathrm{mL}$ concentration.

Among different NQs mentioned above, lapachol (E in Table 1) has been regularly reported to have antibacterial and anticancer properties [51]. Lapachol has been derivatized to produce a pharmacologically important molecule. Zani et al. [38] had isolated lapachol from Tabebuia ochracea (Bignoniaceae family), which was further derivatized by Souza et al. [39] to produce thiosemicarbazone and semicarbazone. In an antibacterial assay, E. faecalis and S. aureus were found to be susceptible to thiosemicarbazone lapachol $(0.05 \mu \mathrm{mol} / \mathrm{mL})$ and semicarbazone lapachol $(0.10 \mu \mathrm{mol} / \mathrm{mL})$. Along with Bignoniaceae, many other families like Verbenaceae, Proteaceae, Leguminosae, Sapotaceae, Scrophulariaceae, and Malvaceae show broad scope to extract lapachol.

An interesting report by Balachandran et al. [52] documented the isolation of an antibacterially bioactive 1,4 NQ molecule from Streptomyces sp., named bluemomycin, using EA. The EA extract displayed potent antibacterial activity against both Gram-negative bacteria as well as Gram-positive bacteria.

In the view of the present scenario, it is also vital to communicate that the microorganisms used for antimicrobial assays are S. aureus, P. aeruginosa, and E. coli, which belong to the ESKAPE category. At lower MICs, most NQs of natural origin have demonstrated better activities against Gram-positive (Staphylococcus spp., Bacillus spp.) than Gram-negative bacteria. Among Gram-negative bacteria, Pseudomonas spp. and E. coli have been frequently tested to determine the antibacterial potency of NQs (Figure 2).

\subsection{Chemically Synthesized 1,4-Naphthoquinone Derivatives}

Just like those of a natural origin, chemically derivatized 1,4-NQs are widely investigated for antimicrobial potential. Literature suggests that most of the additions or deletions of the chemical groups have been carried out at 2nd and 3rd positions in NQ moieties. The groups preferred for additions are $\mathrm{H}, \mathrm{OH}, \mathrm{CH}_{3}, \mathrm{Cl}, \mathrm{Br}, \mathrm{N}$, and $\mathrm{S}$. Most of the chemical elements chosen for derivatization are placed from 14 to 17 in the periodic table. These atoms are typically reactive non-metals and strong oxidizing agents.

Chemical modifications in the NQ moieties have been facilitated to explore them for a wide range of biological applications. Ravichandiran et al. [53] synthesized a series of NQs containing phenylamino-phenylthio moieties and evaluated their antibacterial activity against S. aureus, Listeria monocytogenes, E. coli, P. aeruginosa, and K. pneumonia with MICs ranging between 15.6 to $500 \mu \mathrm{g} / \mathrm{mL}$. Most of the synthesized NQ derivatives were able to inhibit $S$. aureus and E. coli. However, NQ derivatives were found to be less effective against the other three strains. The structure-activity relationship (SAR) suggested that the introduction of the thiophenol group in one of the structures can exhibit moderate antibacterial activity as compared to its ligand. This study revealed that the introduction of a substituted amide group, acid chlorides (aliphatic and aromatic), in one of the compounds shows superior antibacterial properties as compared with its parent compound. Likewise, a compound containing a 3,5-dinitro aryl moiety displayed enhanced antibacterial activity against selected pathogens. Contrary to this, synthesized compounds having a bulky moiety or electron-withdrawing groups $\left(\mathrm{NO}_{2}\right.$ and methyl) showed low inhibitory actions against test cultures. This can be further justified by the fact that the bulky groups cannot enter or penetrate easily into the bacterial cell and thus, encounter challenges to fit at the target sites [53]. The synthesis of quinones substituted with $\mathrm{N-}, \mathrm{S}-, \mathrm{O}-$ and the evaluation of their antimicrobial and anticancer activities was performed by Kurban et al. [18]. For the first time, researchers documented the efficiency of benzo- and NQ derivatives to inhibit an enzyme, catalase (which is responsible for the decomposition of $\mathrm{H}_{2} \mathrm{O}_{2}$ into $\mathrm{H}_{2} \mathrm{O}$ and $\mathrm{O}_{2}$ to protect cells from oxidative damage).

From the literature, it is noteworthy that the bacterial species of the ESKAPE category are extensively tested to assess the efficacies of chemically synthesized NQ derivatives. NQs 
can impose greater effects against Gram-positive bacteria. However, it is also important to highlight the exceptional cases wherein Gram-negative strains like K. pneumoniae and E. coli are also susceptible to some of the NQ derivatives $[53,54]$. The mechanism of action might be influenced by the constituents of the cell wall. Also, the interaction of the functional groups of NQ derivatives at the target position is another parameter which cannot be neglected. The addition or deletion of a single chemical group (for example $\mathrm{OH}, \mathrm{Cl}, \mathrm{Br}$, $\mathrm{S}, \mathrm{N}$, or $\mathrm{O}$ ) to or from a specific position in a NQ structure can affect the efficacies of the NQ against targeted pathogens. Table 3 presents the antibacterial potential of chemically synthesized NQ derivatives along with their MICs.

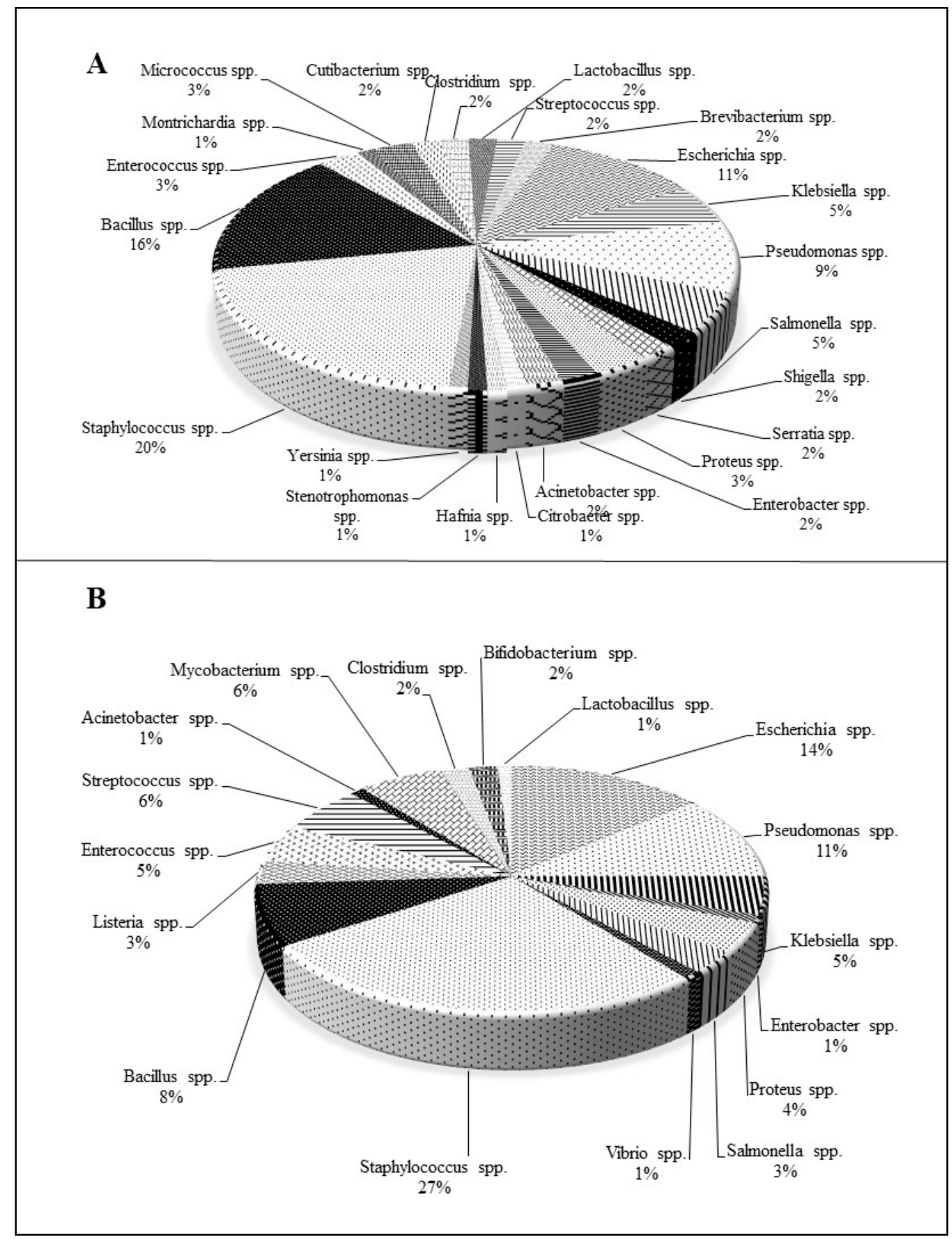

Figure 2. Percentage-wise distribution of bacterial species used to evaluate the antibacterial activity of (A): naturally derived and (B): chemically synthesized 1,4-naphthoquinones. 
Yap et al. [55] put forth findings that demonstrated the synergistic relationship between 1,4-NQ and antibiotics like imipenem, cefuroxime, and cefotaxime against methicillinresistant Staphylococcus aureus (MRSA). Authors suggest that 1,4-NQ could be developed into an adjuvant that will help in enhancing the function of antibiotics against drug-resistant bacteria as a part of combination therapy.

Table 3. Antibacterial potential of chemically synthesized naphthoquinones along with their minimum inhibitory concentration (MIC).

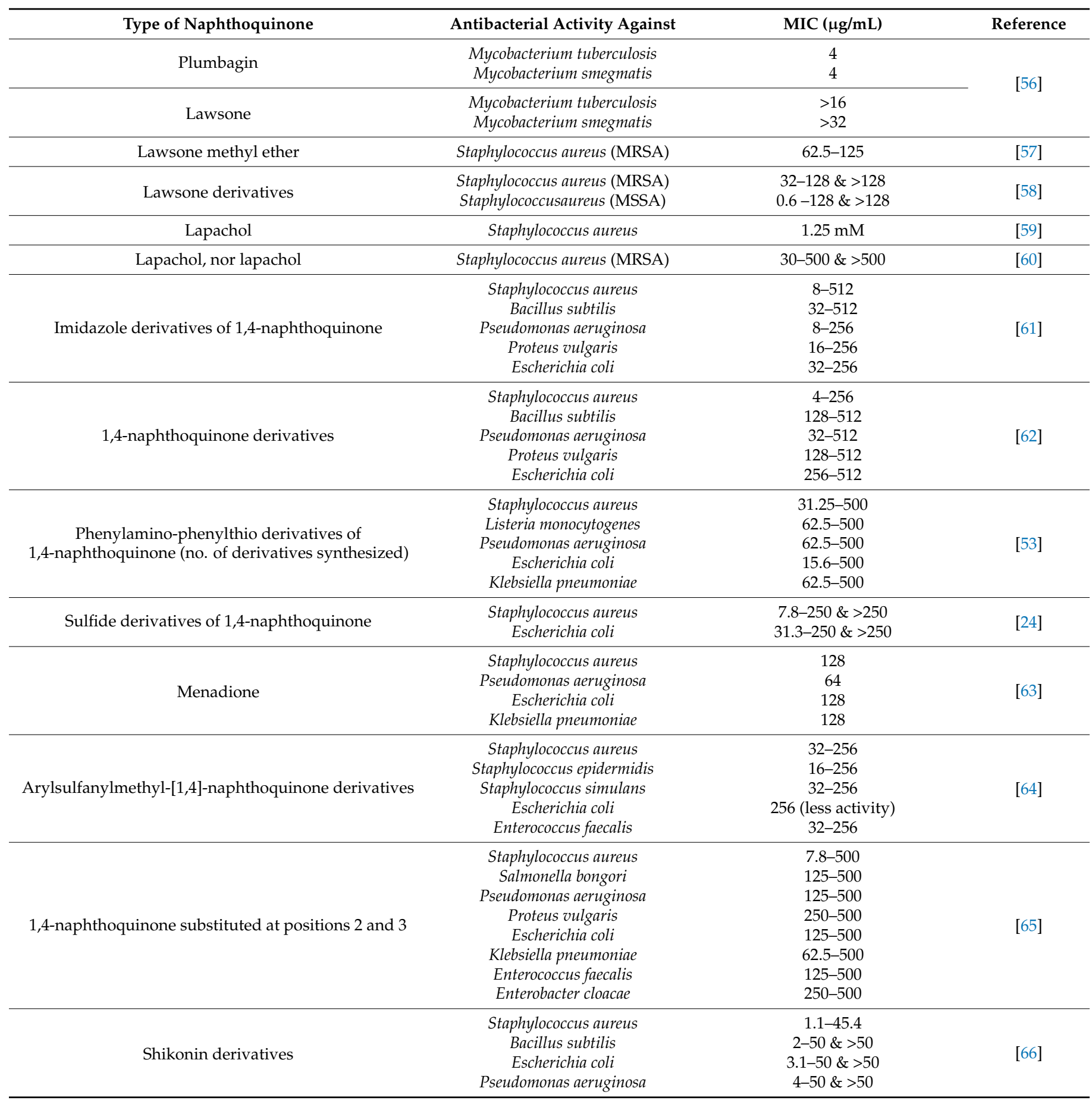


Table 3. Cont.

\begin{tabular}{|c|c|c|c|}
\hline Type of Naphthoquinone & Antibacterial Activity Against & $\operatorname{MIC}(\mu \mathrm{g} / \mathrm{mL})$ & Reference \\
\hline Naphthoquinone derivatives & $\begin{array}{c}\text { Staphylococcus aureus } \\
\text { Pseudomonas aeruginosa } \\
\text { Escherichia coli } \\
\text { Enterococcusfaecalis }\end{array}$ & $\begin{array}{l}16-256 \\
64-256 \\
64-256 \\
64-256\end{array}$ & \multirow[t]{2}{*}[19]{} \\
\hline 2-bromo-5-hydroxy-1,4-NQ & Staphylococcus aureus & 16 & \\
\hline Juglone & $\begin{array}{c}\text { Staphylococcus aureus } \\
\text { Staphylococcus epidermidis } \\
\text { Bacillus cereus } \\
\text { Salmonella enterica } \\
\text { Listeria monocytogenes } \\
\text { Pseudomonas aeruginosa } \\
\text { Escherichia coli } \\
\text { Enterococcus feacalis } \\
\text { Vibrio alginolyticus }\end{array}$ & $\begin{array}{c}32-256 \\
128 \\
256 \\
256 \\
256 \\
128 \\
128 \\
256 \\
256\end{array}$ & {$[67]$} \\
\hline Nitrogen and sulfur derivatives of 1,4-naphthoquinone & $\begin{array}{l}\text { Bacillus subtilis } \\
\text { Proteus vulgaris }\end{array}$ & $\begin{array}{c}1.4-19.3 \\
2.7-39\end{array}$ & {$[68]$} \\
\hline $\begin{array}{l}\text { Plumbagin, juglone, lawsone, menadione and their } \\
\text { analogues }\end{array}$ & $\begin{array}{l}\text { Staphylococcusaureus (MRSA) } \\
\text { Pseudomonas aeruginosa }\end{array}$ & $\begin{array}{c}\text { 3.9-125 } \\
\text { No significant activity }\end{array}$ & {$[69]$} \\
\hline Menadione & $\begin{array}{l}\text { Staphylococcus aureus } \\
\text { Bacillus anthracis } \\
\text { Streptococcus pyogenes } \\
\text { Streptococcus agalactiae }\end{array}$ & $\begin{array}{c}3.1 \\
6.25 \\
25 \\
6.25\end{array}$ & \multirow{2}{*}[70]{} \\
\hline 1,4-naphthoquinone & $\begin{array}{l}\text { Staphylococcus aureus } \\
\text { Bacillus anthracis } \\
\text { Streptococcus pyogenes } \\
\text { Streptococcus agalactiae }\end{array}$ & $\begin{array}{c}6.25 \\
12.5 \\
50 \\
12.5\end{array}$ & \\
\hline $\begin{array}{l}\text { 2-hydroxy, 1,4 naphthoquinone (Lawsone) and its } \\
\text { 2-hydroxynaphthoquinone derivatives }\end{array}$ & $\begin{array}{c}\text { Staphylococcus aureus } \\
\text { Listeria monocytogenes } \\
\text { Pseudomonas aeruginosa } \\
\text { Escherichia coli } \\
\text { Enterococcus faecalis } \\
\text { Acinetobacter baumannii } \\
\text { Salmonella typhimurium }\end{array}$ & $\begin{array}{c}16-512 \&>512 \\
512 \&>512 \\
512 \&>512 \\
512 \&>512 \\
256-512 \\
512 \&>512 \\
512 \&>512\end{array}$ & {$[71]$} \\
\hline Plumbagin derivatives & $\begin{array}{l}\text { Mycobacterium smegmatis } \\
\text { Mycobacterium tuberculosis }\end{array}$ & $\begin{array}{l}13.3-30.4 \\
15.6-77.4\end{array}$ & {$[72]$} \\
\hline $\begin{array}{l}\text { Nitrogen, sulfur groups substitution at } 2,3 \text { positions of } \\
\text { 1,4-naphthoquinone }\end{array}$ & $\begin{array}{l}\text { Staphylococcus aureus } \\
\text { Escherichia coli } \\
\text { Klebsiella pneumoniae }\end{array}$ & $\begin{array}{l}6.25-50 \&>50 \\
6.25-50 \&>50 \\
1.56-50 \&>50\end{array}$ & [73] \\
\hline 5-Hydroxy-2-methyl-1,4-NQ & Clostridium perfringens & & \multirow{4}{*}[30]{} \\
\hline \multirow{2}{*}{ 1,4-naphthoquinone } & $\begin{array}{l}\text { Lactobacillus casei } \\
\text { Bifidobacterium bifidum }\end{array}$ & & \\
\hline & $\begin{array}{c}\text { Bifidobacterium breve } \\
\text { Clostridium perfringens } \\
\text { Escherichia coli }\end{array}$ & $\begin{array}{c}\text { Antibacterial activity observed } \\
\text { however MIC values are not } \\
\text { mentioned specifically for the test } \\
\text { organisms }\end{array}$ & \\
\hline 1,2-naphthoquinone & $\begin{array}{l}\text { Clostridium perfringens } \\
\text { Bifidobacterium bifidum } \\
\text { Bifidobacterium breve }\end{array}$ & & \\
\hline 5-Amino-8-Hydroxy-1,4-NQ & Staphylococcus aureus & 50 & \multirow{2}{*}[74]{} \\
\hline 1,4-naphthoquinone & Staphylococcus aureus & 10 & \\
\hline $\begin{array}{l}\text { (L)-a-amino acid methyl ester, heteroalkyl and aryl } \\
\text { substituted1,4-naphthoquinone derivatives }\end{array}$ & $\begin{array}{c}\text { Staphylococcus aureus } \\
\text { Streptococcus faecalis } \\
\text { Klebsiella pneumoniae } \\
\text { Escherichia coli } \\
\text { Pseudomonas aeruginosa }\end{array}$ & $\begin{array}{l}12.5-50 \&>50 \\
12.5-50 \&>50 \\
6.25-50 \&>50 \\
12.5-50 \&>50 \\
50 \&>50\end{array}$ & [54] \\
\hline
\end{tabular}


From the overall literature survey, 1,4-NQs extracted from natural sources and synthesized by chemical means propose their extraordinary candidature against pathogens. The percentage-wise distribution of bacterial species evaluated to demonstrate antibacterial potential of 1,4-NQs is depicted in Figure 2. Staphylococcus spp. belonging to the ESKAPE and MDR pathogen groups has been reported frequently for its susceptibility towards natural ( 20\%) and chemically synthesized ( 27\%) NQs. Followed by Staphylococcus spp., other Gram-positive bacteria, namely, Bacillus spp. ( 16\%), have been used to validate the antibacterial activity. Among Gram-negative bacteria, E. coli ( 11\%) and Pseudomonas spp. $(\sim 9 \%)$ seemed to be used for in vitro assays. In addition to the above-mentioned prominent bacteria, several other organisms have been utilized in experiments. Like the natural NQs, chemically synthesized NQ derivatives have generally been tested against Pseudomonas spp. and E. coli (both members of the ESKAPE and MDR pathogen groups). Organisms, viz. E. faecium, K. pneumoniae, A. baumannii, and Enterobacter spp. of ESKAPE, have been assessed for the antibacterial efficiency of NQs (Figure 2). The pragmatic analysis of 1,4-NQs, overtly showcases them as an emerging drug against the targeted pathogens.

\section{Structure-Activity Relationship and Bioinformatics Approach: Determining the Possible Mechanistic Role of 1,4-Naphthoquinones at the Molecular Level in a Cell}

Currently, computational tools like artificial intelligence and machine learning have been suggested to enhance the simulation and modeling processes for nanotherapeutics [75-77]. SAR studies aid in understanding the probable mechanistic role of NQs at the molecular level in a biological system. It can be figured out that the chemical modifications of NQs, through the addition or removal of a specific chemical group like the halides, thiolated at particular positions (C-2 and C-3) in a parent molecule, can drastically affect its activity. Research conducted by Wellington et al. [24] highlights the SAR of the NQ derivatives with an antibacterial effect on E. coli. The activity of these compounds was dependent on the fluoro group present on the phenyl ring. The fluoro group at metaposition exhibits better activity (MIC $31.3 \mu \mathrm{g} / \mathrm{mL})$ than that at para-position $(93.3 \mu \mathrm{g} / \mathrm{mL})$. The addition of two fluoro groups, one at meta- and other at para-position, drastically reduced the antibacterial activity of chemically synthesized NQ derivatives (MIC of $187.5 \mu \mathrm{g} / \mathrm{mL}$ ). Also, the addition of 3-sulfanylpropanoic acid to the original compound (1,4-NQs) displayed the weakest activity $(250 \mu \mathrm{g} / \mathrm{mL})$ against $E$. coli. Another study conducted by Sánchez-Calvo et al. [19] presented exciting data on the presence of halogen derivatives $(\mathrm{Cl}, \mathrm{Br})$ at the $\mathrm{C}-2$, and $\mathrm{C}-3$ positions, while the carbonyl group at the $\mathrm{C}-1$ and $\mathrm{C}-4$ positions influence the antimicrobial activity of NQs. Furthermore, side chains with $>10$ carbon atoms can diminish the antimicrobial potential of NQs due to the upsurge in lipophilic character. The hydroxyl group at C-5 and/or C-8 also enhances the activity of NQ derivatives up to a noticeable limit. If it is further replaced by other functional groups, then antimicrobial activity is reduced considerably. This proves the importance of core rings of NQ with respect to antibacterial activity. Ravichandiran et al. [68] evaluated nitrogen- and sulfur-bearing quinone derivatives for antibacterial activity. Heterocyclic quinone derivatives bearing a nitro group (with strong electron-withdrawing power) exhibit momentous antibacterial and anticancer potential.

The molecular docking approach is another hopeful area to reveal better understanding about the interactions of chemical entities at the molecular level. Ravichandiran et al. [53] successfully studied the possible molecular interactions of the selected NQ derivative (5a) against the crystal structure of the cytoplasmic chaperone, DmsD protein, (which is required for the synthesis of dimethyl sulphoxide-DMSO reductase) belonging to E. coli. Structurally, the 5 a derivative has a hydrogen atom at a significant position. The docking analysis confirmed the binding of the ligand in the cavity of the DmsD protein molecule. Authors documented the formation of a hydrogen bond with ARG A15 (arginine A15 residue), with a corresponding active site, along with $\pi-\pi$ stacking. Authors also dragged readers' attention towards electrochemical studies on the reduction potential of the derivatives. The compound 5 a has the highest reduction potential, which correlates to 
the lower MIC value. This justifies the hypothesis of the significance of redox behavior in governing the antibacterial activity of NQs.

Computational modeling is also a trustworthy approach to predict the functioning of a complex system supported through computer simulation. Figueredo et al. [60] investigated the pharmacological potential of 2-(2-hydroxyethylamine)-3-(3-methyl-2-butenyl)1,4-dihydro-1,4-naphthalenedione, 2-(2-hydroxy-ethylamine)-3-(2-methyl-propenyl)-(1,4) naphthoquinone, and 2(3-hydroxy-propylamine)-3-(3-methyl-2-butenyl)-(1,4) naphthoquinone alkaloid analogues of lapachol and nor lapachol. The antibacterial-potential study was also supplemented with computational prediction modeling data. In silico studies (through ChEMBL database), it has been revealed that 2-(2-hydroxy ethylamine) -3-(2-methyl-propenyl)-(1,4) naphthoquinone could be a possible drug to target replicative DNA helicase and RecA. Another report published by Figueredo et al. [78] explained the possible interaction of alkaloid analogues derived from lapachol and nor lapachol with the NorA efflux pump (in S. aureus). This association study, conducted with molecular docking, indicated noticeable reduction in MICs (Table 4) and also the inhibition of the activity of the NorA efflux pump with high affinity.

A few years back, Qiu et al. [66] used a docking simulation study to approach the shikonin compound as a tyrosyl-tRNA synthetase (TyrRS) inhibitor. Scaffold modification of shikonin was carried out through in vitro primary screening. This study continued the demonstration of the inhibitory effect of modified shikonin against TyrRS and selected bacterial strains. One of the derivatives, namely, PMM-154, was identified as the most potent compound against S. aureus ATCC 25923 (MIC of $1.1 \mathrm{mg} / \mathrm{mL}$ ) with the apoptosis effect. The outcome of this study confirmed the modification of the phenyl ring of phenylpiperazine at the third position by trifuoromethyl to propose PMM-154 as a promising TyrRS inhibitor to deal with infections caused by microbial pathogens.

\section{Possible Mechanistic Roles of Napthoquinones}

The multifunctionalities of NQs, like antibacterial, antifungal, antiparasitic, etc. functions, make them a propitious armory to combat MDR and ESKAPE pathogens. Sparse but meticulous literature is available on the mechanistic roles of NQs against pathogens. NQs are expansively studied for their anticancer activities through the production of ROS and subsequent apoptosis of cancer cells [79,80]. NQs are also recognized to inhibit topoisomerases in cancer cells [81]. However, surprisingly for their antimicrobial potential, they have been reasonably less discovered. Therefore, a few questions related to the mechanistic roles of NQs in biological systems remain unanswered. Here, we list out some of the possible mechanisms responsible for antibacterial potential of NQs in biological systems. Literature suggests that among all NQ derivatives known, juglone has been most studied in depth for mechanistic perspectives, like the (1) ability to cure plasmids from bacteria, (2) interference with the activity of EPs, (3) generation of ROS, and (4) activity of the topoisomerase enzyme. Bioactive molecules from Plumbago species have fascinated scientific fraternities due to their abilities to cure plasmids from bacteria. It is also remarkable to state that the molecular weights (ranging from 170 to $300 \mathrm{gm} / \mathrm{mol}$ ) of natural sourced NQs like lawsone, plumbagin, juglone, shikonin, and menadione are less than the molecular weights of conventional antibiotics like penicillin, streptomycin, ciprofloxacin, and tetracycline (ranging from 330 to $582 \mathrm{gm} / \mathrm{mol}$ ). This is a striking indication that these NQs are not bulky molecules and consequently can enter easily in the cell provided there is a favorable charge on the compound with a compatible chemical nature of side groups attached. NQs can perform their function through the above-mentioned mechanisms, which is explained in the following sections.

\subsection{Efficiency to Cure Plasmids from Bacteria}

Plasmids are well accepted as a "vehicle" to communicate genetic information among bacteria [82]. Plasmids are generally circular, extrachromosomal DNA elements where characteristic copy numbers are maintained in the host cell. Based on their functional prop- 
erties, plasmids are classified as either (1) fertility (F-plasmids), (2) resistance (R-plasmids), or (3) virulence, (4) degradative, or (5) col plasmids. These plasmids encode properties like resistance to various antibiotics, virulence, the ability to degrade heavy metals or aromatic compounds, etc. Some plasmids bear the capacity to degrade hydrocarbons, synthesizing bacteriocins $[83,84]$. Resistance to antibiotics is spread through vertical (from parents to the next generation/offspring) and horizontal transfer (across genera or species). The spread of infection or antibiotic resistance can be restricted by inhibiting the conjugational transfer of plasmids. If a bacterial population loses plasmid/s, they may lose plasmid-borne characteristics. This process is known as curing. This process can be demonstrated in the laboratory with the help of curing agents like ethidium bromide (EtBr), acridine orange $(\mathrm{AO})$, acriflavine (AF), and sodium dodecyl sulphate (SDS). None of the plasmid-curing agents can obviate all plasmids present in diverse hosts. Therefore, it becomes mandatory to investigate innovative molecules that can work as effective curing agents. Plasmidcuring compounds impose activity through (1) disrupting the replication of plasmids by integrating into the DNA, (2) producing breaks in the DNA, and (3) preventing conjugation or influencing plasmid supercoiling. These consequences lead to a reduction in the occurrence of plasmids within the population over time [85]. Replication of plasmids can be prohibited at various stages, and this concept has been well established through the "rolling circle" model [86]. Plasmid curing-the process of removal or obviating plasmids from bacteria-is depicted in Figure 3.

The literature suggests that NQs have abilities to cure plasmid/s from bacterial populations (Figure 3). The curing of plasmids from bacterial communities could be one of the conceivable mechanisms of action of NQs. Over the last 25 years, researchers have gained interest in NQs and their derivatives for plasmid-curing activities. Lakshmi and Thomas [87] reported plumbagin to cure F-like plasmid TP18 as well as attacking roles on DNA gyrase. Authors also revealed that the plasmid-curing abilities of plumbagin might be due to interference with the replication of miniTP181. Subsequently, there is a reduction in the copy number of plasmids along with an enhanced rate of segregation. The efficiency of plasmid curing is calculated from the number of colonies exhibiting the reversal of plasmid-borne character (for example, resistance to antibiotics) per 100 colonies tested (Figure 3). The efficiency of plasmid curing certainly varies and is dependent not only on the plasmid but also its typical host. Beg and Ahmad [88] reported 14\% plasmid (pUK651 from E. coli $\mathrm{x}+$ )-curing efficiency in P. zeylanica (root) ethanolic lawsone extracts. Patwardhan et al. [34] showed lawsone could cure plasmids pBR322 and pRK2013 with curing efficiency of 11 and 20\% respectively. Plasmid R136 seen in S. typhi was cured at $4.2 \%$ curing efficiency without any effect on plasmid RP4, found in E. coli. The plasmids having a molecular weight ranging from 4.3 to $56.4 \mathrm{~Kb}$ were cured fruitfully. Similarly, Patwardhan et al. [32] have also documented the effect of P. auriculata root extracts on nosocomial pathogens. Authors also proved the reversal of plasmid resistance to antibiotics in pathogens. P. auriculata root extract contains a variety of NQs, including plumbagin. Plasmids from P. aeruginosa (with 13\%), E. coli (with 15\%), P. vulgaris (with 32\%), and K. pneumoniae (with 30\%) were cured successfully. The curing efficiencies of root extracts stated here were significantly higher than AO (a reference curing agent). Therefore, the plasmid-curing abilities of NQs are noteworthy strategies if used in combination with antibiotics. The plasmid-curing abilities of a chemical will not kill pathogens directly; nevertheless, it will increase the susceptibility of pathogens towards antibiotics due to the loss of plasmid-borne resistance.

\subsection{Inhibition of Efflux Pumps (EPS)}

As a strategy of drug resistance, Gram-negative bacteria possess EPs that facilitate the movement of drug molecules outside the cell (generally in a nonspecific manner that confers resistance to bacteria against multiple antibiotics) $[89,90]$. EPs have the capability to extrude not only antibiotics but also other several organic pollutants and heavy metals. 
The entire mechanism of action of EPs under the active and inhibited state (due to the action of NQs) is portrayed in Figure 4.

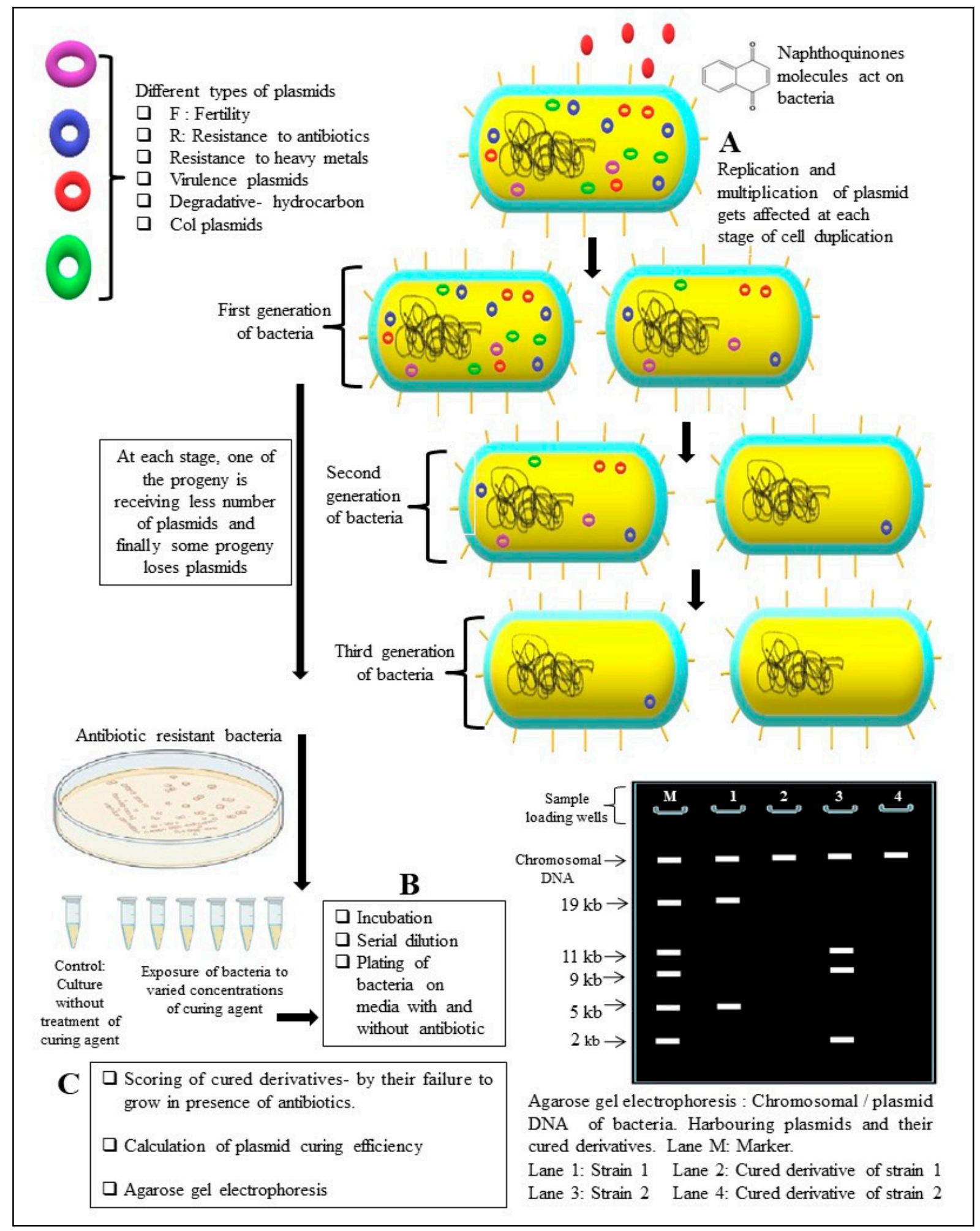

Figure 3. Plasmid curing - a possible mechanism of action for naphthoquinones. (A): Replication and multiplication of plasmid/s is affected at each stage of cell duplication. (B): Exposure of a bacterial culture to varied concentrations of curing agents, followed by the incubation, serial dilution, and plating of the culture on media with and without antibiotic. (C): Scoring of cured derivatives-by their failure to grow in presence of antibiotic/s. Calculation of plasmid curing efficiency - number of colonies displaying reversal of resistance to antibiotic/s per 100 colonies tested. Performance of agarose gel electrophoresis-to confirm the removal/obviation of plasmid DNA from the strain treated with a curing agent. 


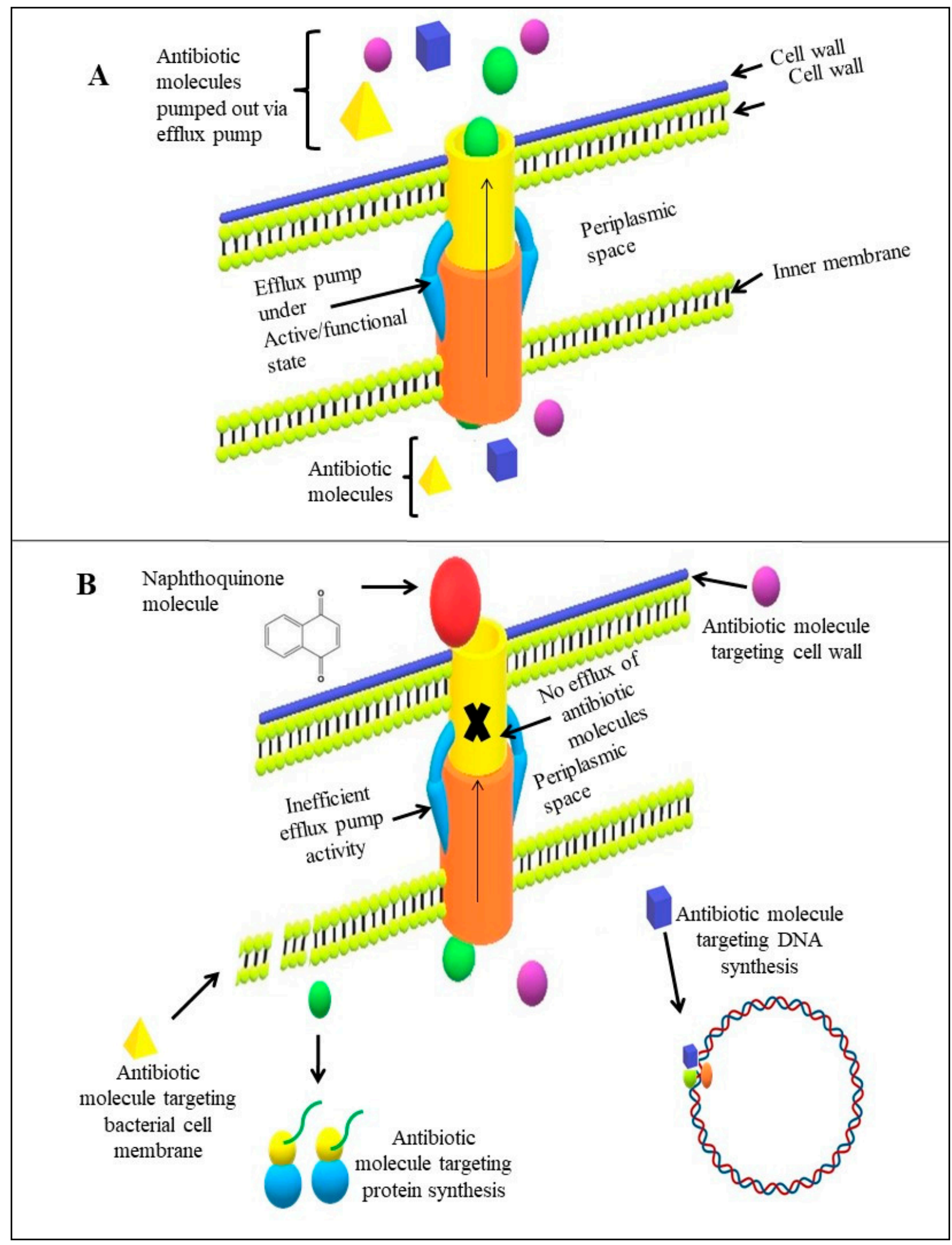

Figure 4. Interference with the activity of efflux pumps through the action of naphthoquinones. (A): efflux pumps under an active state conferring resistance against antibiotic molecules by pumping them outside the bacterial cell. (B): inhibition of efflux pumps by naphthoquinone molecule, resisting it from the efflux of antibiotic molecules and therefore, making the cell sensitive to antibiotics. 
Plant-derived compounds, quorum-sensing signal molecules, and bacterial metabolites are reported to interfere with the activity of EPs. The functional status of EPs plays a decisive role in bacterial response to the surroundings. EP-mediated multidrug resistance is advantageous for bacterial communities in intrinsic, acquired, and phenotypic ways. Bacterial EPs are classified in the (1) resistance-nodulation-division (RND) family, (2) small multidrug resistance (SMR) family, (3) major facilitator superfamily (MFS), (4) multidrug and toxic compound extrusion (MATE) family, and (5) the adenosine triphosphate (ATP) binding cassette $(\mathrm{ABC})$ superfamily. A single EP can pump out a wide range of antibiotics [91]. The inhibition of EPs guarantees the enhanced susceptibility of bacteria towards antimicrobial agents and also make them suitable targets.

Compounds like piperine [92], 5'-methoxy-hydnocarpin [93], quinoline derivatives [94] etc. have been reported to interfere with or affect EPs in several bacteria. An interesting fact about these chemicals is that they contain a ring structure that is a crucial part of NQs. Among those in the ESKAPE and MDR category, S. aureus shows the presence of EPs. Zmantar et al. [67] reported the ability of juglone (at $182-256 \mu \mathrm{g} / \mathrm{mL}$ ) to inhibit (50\%) the EPs of S. aureus and the accumulation of chemicals in the cells. It is worth noting that juglone at the same concentration (182-256 $\mu \mathrm{g} / \mathrm{mL})$ inhibits the efflux of EtBr. Like juglone, plumbagin and shikonin also interfere with the functionalities of EPs. Ohene-Agyei et al. [95] provided evidence that plumbagin and shikonin can inhibit the EPs of E. coli. EPs are mainly utilized for the removal of the substrate from bacteria. It has been observed that AcrB-mediated substrate EPs become affected and inhibited in the presence of NQs. Antibiotics or other antimicrobial-agent-based therapy, in combination with NQ, result in the inhibition of EPs in bacteria. Table 4 represents the MICs of NQ derivatives when used individually and in combination with antimicrobial compounds inhibiting the activity of EPs. The MIC of antimicrobial compounds may be reduced several-fold when they are used in combination or in a synergistic way with other compounds like NQs while performing biological assays.

Table 4. Naphthoquinone derivatives inhibiting the activity of efflux pumps in bacteria.

\begin{tabular}{|c|c|c|c|c|c|}
\hline \multirow{2}{*}{ Test Organism } & \multicolumn{2}{|c|}{ MIC of Antimicrobial Compound } & \multirow{2}{*}{$\begin{array}{c}\text { MIC of } \\
\text { NQs/Substances } \\
\text { (S)/Derivatives } \\
\text { (Individual) }\end{array}$} & \multirow{2}{*}{$\begin{array}{c}\text { MIC of } \\
\text { Antimicrobial } \\
\text { Compound with } \\
\text { NQs }\end{array}$} & \multirow{2}{*}{ Reference } \\
\hline & $\begin{array}{l}\text { Name of the } \\
\text { Antimicrobial } \\
\text { Compound }\end{array}$ & $\begin{array}{l}\text { MIC of AC } \\
\text { (Individual) }\end{array}$ & & & \\
\hline- & \multicolumn{3}{|c|}{$\mathrm{MIC}$ in $\mu \mathrm{g} / \mathrm{mL}$} & & - \\
\hline- & \multirow{3}{*}{$\begin{array}{l}\text { Ethidium bromide } \\
\qquad(\mathrm{EtBr})\end{array}$} & $\mathrm{EtBr}$ & \multirow{3}{*}{$\begin{array}{l}\geq 1024(\mathrm{~S} 3) \\
\geq 1024(\mathrm{~S} 4) \\
\geq 1024(\mathrm{~S} 5)\end{array}$} & $\begin{array}{l}\text { With } 1 / 8^{\text {th }} \text { MIC of S3, } \\
\text { S4 and S5 }\end{array}$ & \multirow{3}{*}{ [78] } \\
\hline $\begin{array}{c}\text { Staphylococcus aureus } \\
\text { SA-1199 } \\
\text { (wildtype -WT) }\end{array}$ & & 64 & & $\begin{array}{l}\text { S. aureus }(\mathrm{WT}) \\
16(\mathrm{EtBr}+\mathrm{S} 3) \\
32(\mathrm{EtBr}+\mathrm{S} 4) \\
32(\mathrm{EtBr}+\mathrm{S} 5)\end{array}$ & \\
\hline $\begin{array}{c}\text { Staphylococcus aureus } \\
\text { SA-1199B strain } \\
\text { (expressing norA gene } \\
\text { expressing NorA efflux protein) }\end{array}$ & & 256 & & $\begin{array}{l}\text { S. aureus (NorA) } \\
32(\mathrm{EtBr}+\mathrm{S} 3) \\
128(\mathrm{EtBr}+\mathrm{S} 4) \\
64(\mathrm{EtBr}+\mathrm{S} 5)\end{array}$ & \\
\hline- & \multirow{3}{*}{ Norfloxacin (NF) } & Norfloxacin & \multirow{3}{*}{$\begin{array}{l}\geq 1024(\mathrm{~S} 3) \\
\geq 1024(\mathrm{~S} 4) \\
\geq 1024(\mathrm{~S} 5)\end{array}$} & - & \multirow{3}{*}[78]{} \\
\hline $\begin{array}{l}\text { Staphylococcus aureus } \\
\text { SA-1199 wildtype }\end{array}$ & & 32 & & $\begin{array}{c}\text { S. aureus }(\mathrm{WT}) \\
1(\mathrm{NF}+\mathrm{S} 3) \\
2.51(\mathrm{NF}+\mathrm{S} 4) \\
4(\mathrm{NF}+\mathrm{S} 5) \\
\end{array}$ & \\
\hline $\begin{array}{l}\text { Staphylococcus aureus SA-1199B } \\
\text { strain } \\
\text { (expressing nor A gene } \\
\text { expressing NorA efflux protein) }\end{array}$ & & 406.3 & & $\begin{array}{l}\text { S. aureus (NorA) } \\
80(\mathrm{NF}+\mathrm{S} 3) \\
50.8(\mathrm{NF}+\mathrm{S} 4) \\
101.6(\mathrm{NF}+\mathrm{S} 5)\end{array}$ & \\
\hline
\end{tabular}


Table 4. Cont.

\begin{tabular}{|c|c|c|c|c|c|}
\hline \multirow{2}{*}{ Test Organism } & \multicolumn{2}{|c|}{ MIC of Antimicrobial Compound } & \multirow{2}{*}{$\begin{array}{c}\text { MIC of } \\
\text { NQs/Substances } \\
\text { (S)/Derivatives } \\
\text { (Individual) }\end{array}$} & \multirow{2}{*}{$\begin{array}{c}\text { MIC of } \\
\text { Antimicrobial } \\
\text { Compound with } \\
\text { NQs }\end{array}$} & \multirow{2}{*}{ Reference } \\
\hline & $\begin{array}{l}\text { Name of the } \\
\text { Antimicrobial } \\
\text { Compound }\end{array}$ & $\begin{array}{l}\text { MIC of AC } \\
\text { (Individual) }\end{array}$ & & & \\
\hline- & \multicolumn{4}{|c|}{ MIC in $\mu \mathrm{g} / \mathrm{mL}$} & - \\
\hline- & \multirow{10}{*}{ Erythromycin } & Erythromycin & Juglone & $\begin{array}{l}\text { With } \frac{1}{2} \text { MIC of } \\
\text { Juglone }\end{array}$ & \multirow{10}{*}{ [67] } \\
\hline Bacillus cereus & & 128 & 256 & 32 & \\
\hline Escherichia coli & & 64 & 128 & 16 & \\
\hline Salmonella enterica & & 4 & 256 & 2 & \\
\hline Staphylococcus aureus & & 128 & 128 & 16 & \\
\hline Listeria monocytogenes & & 64 & 256 & 16 & \\
\hline Enterococcus feacalis & & 64 & 256 & 32 & \\
\hline Staphylococcus epidermidis & & 32 & 128 & 4 & \\
\hline Staphylococcus aureus & & $16-256$ & $32-256$ & $4-32$ & \\
\hline$($ Oral strains = 8) & & - & - & $\begin{array}{l}\text { (2 to } 8 \text {-fold decrease } \\
\text { in MIC) }\end{array}$ & \\
\hline- & \multirow{10}{*}{ Tetracycline } & Tetracycline & Juglone & $\begin{array}{l}\text { With } \frac{1}{2} \text { MIC of } \\
\text { Juglone }\end{array}$ & \multirow{10}{*}{ [67] } \\
\hline Bacillus cereus & & 2 & 256 & 1 & \\
\hline Vibrio alginolyticus & & 256 & 256 & 64 & \\
\hline Salmonella enterica & & 128 & 256 & 64 & \\
\hline Staphylococcus aureus & & 4 & 128 & 2 & \\
\hline Enterococcus feacalis & & 128 & 256 & 64 & \\
\hline Staphylococcus epidermidis & & 8 & 128 & 2 & \\
\hline Pseudomonas aeruginosa & & 64 & 128 & 32 & \\
\hline Staphylococcus aureus & & $2-32$ & $32-256$ & $1-16$ & \\
\hline (Oral strains = 8) & & - & - & $\begin{array}{l}\text { (2 to } 8 \text {-fold decrease } \\
\text { in the MIC) }\end{array}$ & \\
\hline- & \multirow{11}{*}{$\begin{array}{l}\text { Benzalkonium- } \\
\text { chloride }\end{array}$} & $\begin{array}{l}\text { Benzalkonium- } \\
\text { chloride }\end{array}$ & Juglone & $\begin{array}{l}\text { With } \frac{1}{2} \text { MIC of } \\
\text { Juglone }\end{array}$ & \multirow{11}{*}{ [67] } \\
\hline Bacillus cereus & & 16 & 256 & 4 & \\
\hline Escherichia coli & & 16 & 128 & 8 & \\
\hline Salmonella enterica & & 16 & 256 & 4 & \\
\hline Staphylococcus aureus & & 16 & 128 & 8 & \\
\hline Listeria monocytogenes & & 2 & 256 & 1 & \\
\hline Enterococcus feacalis & & 8 & 256 & 2 & \\
\hline Staphylococcus epidermidis & & 4 & 128 & 2 & \\
\hline Pseudomonas aeruginosa & & 32 & 128 & 16 & \\
\hline Staphylococcus aureus & & $4-16$ & $32-256$ & $1-4$ & \\
\hline \multirow[t]{2}{*}{$($ Oral strains = 8) } & & - & - & $\begin{array}{l}\text { (2 to } 8 \text {-fold decrease } \\
\text { in the MIC) }\end{array}$ & \\
\hline & \multicolumn{3}{|c|}{ MIC in mg/L } & & \multirow{13}{*}{ [95] } \\
\hline \multirow{4}{*}{ Escherichia coli } & \multirow{4}{*}{$\begin{array}{c}- \\
\text { Erythromycin } \\
\text { Chloramphenicol } \\
\text { Tetraphenyl- } \\
\text { phosphonium }\end{array}$} & $\mathrm{AC}$ & Plumbagin & Plumbagin (64) $+\mathrm{AC}$ & \\
\hline & & 256 & \multirow{3}{*}{$\begin{array}{c}128 \\
\text { (Individual MIC) }\end{array}$} & 64 & \\
\hline & & 4 & & 2 & \\
\hline & & 1024 & & 256 & \\
\hline \multirow{4}{*}{$\begin{array}{l}\text { Escherichia coli } \triangle \mathrm{AcrB} \\
\text { (Drug sensitive) }\end{array}$} & \multirow{4}{*}{$\begin{array}{c}- \\
\text { Erythromycin } \\
\text { Chloramphenicol } \\
\text { Tetraphenyl- } \\
\text { phosphonium }\end{array}$} & AC & Plumbagin & Plumbagin (10) + AC & \\
\hline & & 16 & \multirow{3}{*}{$\begin{array}{c}10 \\
\text { (Individual MIC) }\end{array}$} & 16 & \\
\hline & & 1 & & 1 & \\
\hline & & 16 & & 16 & \\
\hline- & - & $\mathrm{AC}$ & Shikonin & Shikonin (256) & \\
\hline Escherichia coli & $\begin{array}{c}\text { Tetraphenyl- } \\
\text { phosphonium }\end{array}$ & 1024 & $>256$ & 64 & \\
\hline- & - & $\mathrm{AC}$ & Shikonin & Shikonin (256) + AC & \\
\hline $\begin{array}{l}\text { Escherichia coli DAcrB } \\
\text { (Drug sensitive) }\end{array}$ & $\begin{array}{l}\text { Tetraphenyl- } \\
\text { phosphonium }\end{array}$ & 16 & $\begin{array}{c}>256 \\
\text { (Individual MIC) }\end{array}$ & 16 & \\
\hline
\end{tabular}


Table 4. Cont.

\begin{tabular}{|c|c|c|c|c|c|}
\hline \multirow{2}{*}{ Test Organism } & \multicolumn{2}{|c|}{ MIC of Antimicrobial Compound } & \multirow{2}{*}{$\begin{array}{c}\text { MIC of } \\
\text { NQs/Substances } \\
\text { (S)/Derivatives } \\
\text { (Individual) }\end{array}$} & \multirow{2}{*}{$\begin{array}{c}\text { MIC of } \\
\text { Antimicrobial } \\
\text { Compound with } \\
\text { NQs }\end{array}$} & \multirow{2}{*}{ Reference } \\
\hline & $\begin{array}{l}\text { Name of the } \\
\text { Antimicrobial } \\
\text { Compound }\end{array}$ & $\begin{array}{l}\text { MIC of AC } \\
\text { (Individual) }\end{array}$ & & & \\
\hline- & - & $\mathrm{AC}$ & $\begin{array}{c}\text { Plumbagin } \\
\text { nordihydroguaretic } \\
\text { acid (NDGA) }\end{array}$ & $\begin{array}{l}\text { Plumbagin NDGA } \\
\qquad(256)+\mathrm{AC}\end{array}$ & \\
\hline \multirow{5}{*}{ Escherichia coli } & Erythromycin & 256 & \multirow{5}{*}{$\begin{array}{c}512 \\
\text { (Individual MIC) }\end{array}$} & 64 & \\
\hline & Chloramphenicol & 4 & & 1 & \\
\hline & Novobiocin & 512 & & 64 & \\
\hline & $\begin{array}{l}\text { Tetraphenyl- } \\
\text { Phosphonium }\end{array}$ & 1024 & & 64 & {$[95]$} \\
\hline & Tetracycline & 1 & & 0.25 & \\
\hline \multirow{6}{*}{$\begin{array}{l}\text { Escherichia coli DAcrB } \\
\text { (Drug sensitive) }\end{array}$} & - & $\mathrm{AC}$ & \multirow{6}{*}{$\begin{array}{c}25 \\
\text { (Individual MIC) }\end{array}$} & NDGA (25) + AC & \\
\hline & Erythromycin & 16 & & 16 & \\
\hline & Chloramphenicol & 1 & & 1 & \\
\hline & Novobiocin & 16 & & 16 & \\
\hline & $\begin{array}{l}\text { Tetraphenyl- } \\
\text { Phosphonium }\end{array}$ & 16 & & 16 & \\
\hline & Tetracycline & 0.5 & & 0.5 & \\
\hline
\end{tabular}

Antimicrobial compound: AC; ethidium bromide: EtBr; norfloxacin: NF; plumbagin nordihydroguaretic acid: NDGA; substances/derivatives: S3, S4, S5.

\subsection{Generation of Reactive Oxygen Species (ROS) in Bacteria}

Reactive oxygen species like $\mathrm{H}_{2} \mathrm{O}_{2}, \mathrm{OH}^{-}$, and $\mathrm{O}^{2-}$ are the accountable candidates for the emergence of lethal response in bacteria. The accumulation of $\mathrm{OH}^{-}$radicals in an uncontrolled fashion may lead to bacterial cell death (due to the peroxidation of essential lipids in the cell). ROS have the abilities to target multiple biomolecules like proteins, DNA, and lipids (building blocks required for the survival of the cell) and exhibit severe impact on cell viability, leading to cell death [96]. This entire mechanism is conceptualized in Figure 5. Successive single-electron reductions are responsible for the production of ROS, though it is a subject of debate whether some researchers have proved the participation of ROS in the 'antibiotic-mediated killing of bacteria' [97].

The literature discusses the fact that compounds similar to benzoquinones are responsible for ROS generation in Mycobacterium tuberculosis [98]. Authors demonstrated that MIC values are highly affected due to the generation of extracellular $\mathrm{H}_{2} \mathrm{O}_{2}$ and therefore are recommended in designing an effective drug strategy. Thus, the generation of high levels of ROS in microbial cells could be a gifted strategy to treat bacterial infections [99]. Ravichandiran et al. [53] proved the action of NQ derivatives against E. coli through the generation of intracellular ROS. Authors also stated that redox behavior is a substantial factor and a possible mechanism of antibacterial activity of NQs. Additionally, the binding of NQs to bacterial membranes is a crucial one to demonstrate its action. Authors supported this fact through (1) the estimation of intracellular ROS, (2) the apoptosis-induced effects (3) bactericidal time-killing, (4) molecular modeling, and (5) an electrochemical study.

Researchers have utilized innovative technologies like isobaric tags for relative and absolute quantitation (iTRAQ) to evaluate the quantitative expression of proteins in cells treated with NQs. Isobaric tags (for assistance with relative and absolute quantitation) are popular as iTRAQ technology. This isobaric labeling technique uses quantitative proteomics through tandem mass spectrometry (MS) to quantify proteins present in varied sources in a single experiment set up. The technique essentially operates through the labeling (covalent interactions) of $\mathrm{N}$-terminus with peptides (side-chain amines) after the digestion of protein with tags (4-plex, 8-plex) possessing speckled mass. Evaluation of data is performed at the peptide level where signals (of the reporter ions) for each MS spectrum are used to calculate the ratio of the relative abundance of the respective peptides identified by the spectrum $[100,101]$. More than one signal appearing in MS data might be due to the abundance of reporter ions. The collective ratios of protein/peptide positively represent the 
relative quantification of a particular protein. Wang et al. [46] applied iTRAQ technology to the analysis of the expression of 53 proteins in S. aureus after treatment with juglone. Oxidative damage was the prime mechanism found to kill S. aureus. Juglone displayed the capability to upregulate the expression of oxidoreductase, resulting in an increase in the redox processes, thereby generating a peroxidative surrounding in the cell. Juglone treatment reduces cell-wall formation significantly and is also accompanied by an increase in cell permeability. Authors also suggested that juglone may impose different mechanisms of action against other bacteria. Another study documented by Linzner et al. [59] falls on parallel lines. Their study proposed the generation of ROS activity by NQs in bacterial cells. Authors also investigated the mode of action of lapachol in S. aureus, indicating the oxidative and quinone stress response. The generation of ROS by NQs is a noticeable antibacterial strategy through various targets like lipids, proteins, and DNA to enhance the susceptibility of bacteria towards ROS-generating compounds (Figure 5).

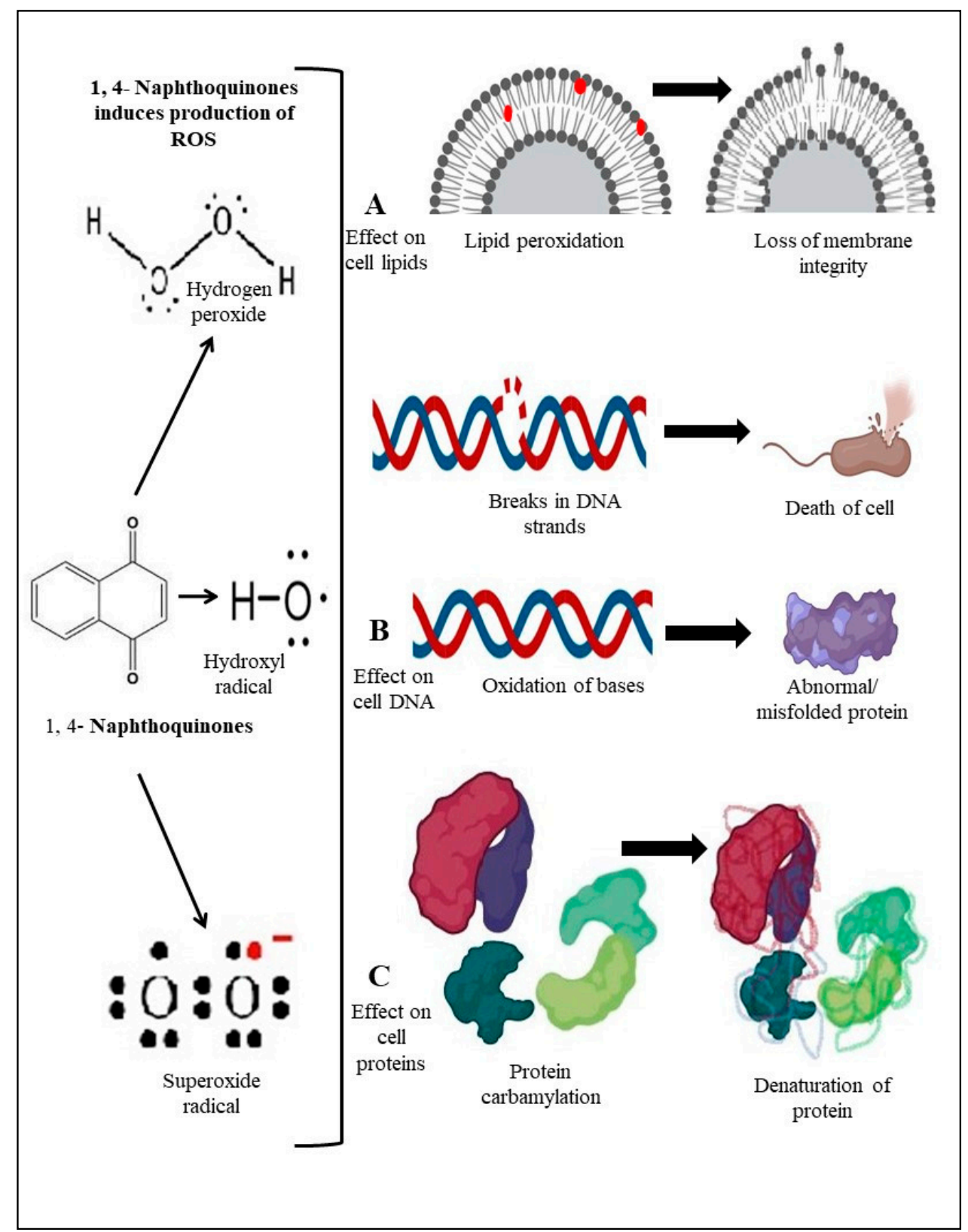

Figure 5. Generation of reactive oxygen species (ROS) - a possible mechanism of action of naphthoquinones. Effect on (A): membrane lipids (B): cell DNA and (C): cell proteins. 


\subsection{Inhibition of Topoisomerase Enzyme}

DNA topoisomerase enzymes are known to regulate and alter the topology of DNA in the cells. Based on their ability to make temporary single- or double-stranded breaks in DNA, topoisomerases are categorized as type I and II respectively [102]. The energy required for enzymatic-induced cleavage is achieved through the hydrolysis of ATP. DNA gyrase represents the bacterial type II topoisomerases, which are recognized for their "highly conserved" functional properties. The entire mechanism promotes DNA replication and transcription processes that are vital for cell survival. These enzymes regulate the topology of bacterial DNA through its cleavage as exemplified in Figure 6A. Malfunctioning of these events eventually results in cell death [103]. Bacterial DNA topoisomearase II (DNA gyrase) is an unquestionable target for antibacterial agents. NQ compounds inhibit the supercoiling activity of DNA. Karkare et al. [104] showed the inhibitory activity of gyrase enzyme in S. aureus, E. coli, and M. tuberculosis using commercially available diospyrin and 7-methyljuglone (Table 5). NQs bind to the N-terminal of GyrB, a novel location close to the ATPase site. These facts provide strong indication to depict a possible mode of action of NQs in organisms (Figure 6A), which can be explored further to develop an innovative antibacterial agent.

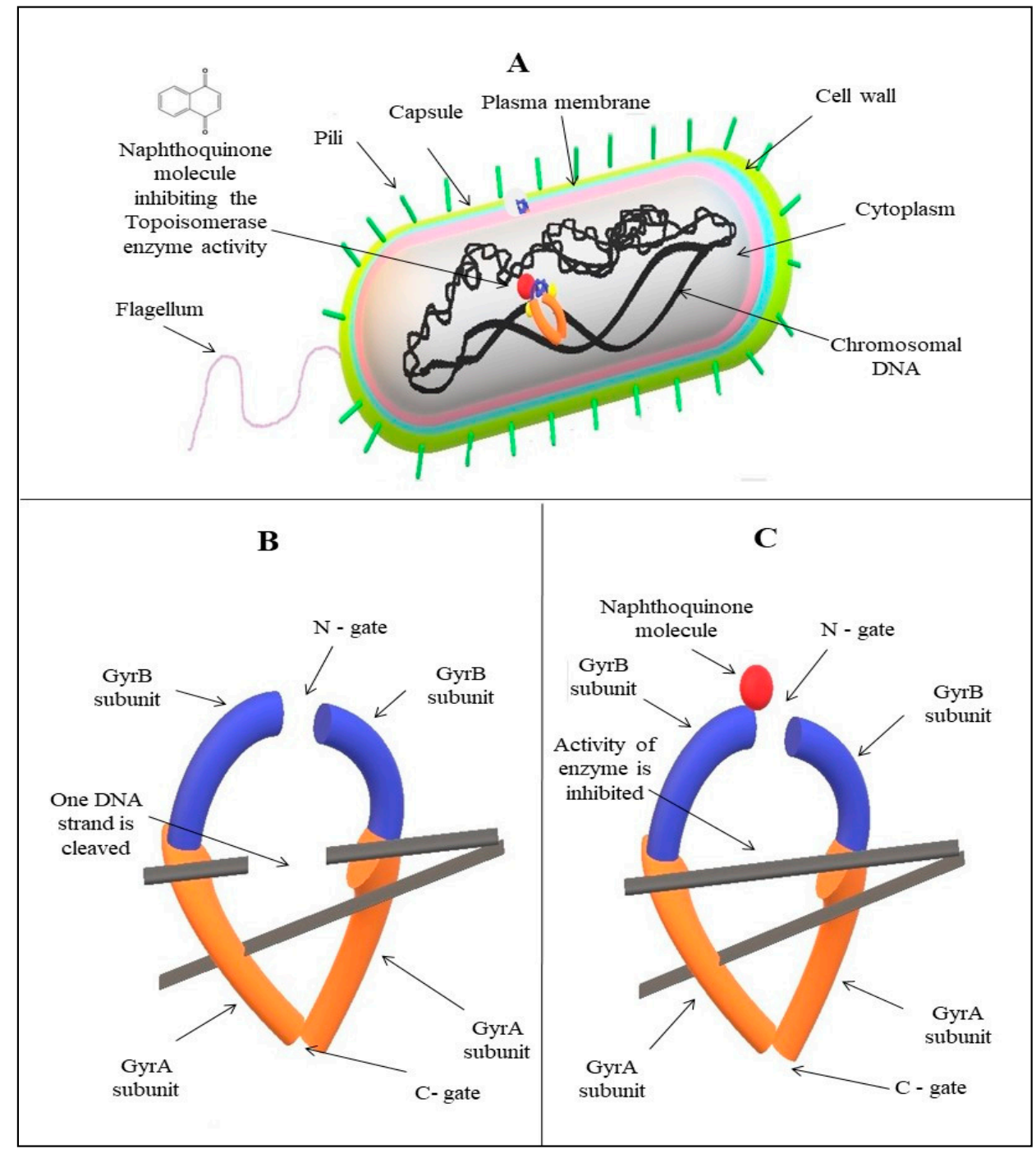

Figure 6. Inhibition of topoisomerase enzyme-a possible mechanism of action of naphthoquinones. (A): interaction of topoisomerase enzyme in the bacterial system. (B): functional state of topoisomerase enzyme: a temporary single stranded break in DNA, $(\mathbf{C})$ : interference with the activity of the topoisomerase enzyme in the presence of naphthoquinone molecules. 
Table 5. Naphthoquinone inhibiting supercoiling activity of enzyme-DNA gyrase (bacterial topoisomerase II).

\begin{tabular}{ccccc}
\hline \multirow{2}{*}{ Test Organism } & \multicolumn{2}{c}{$\begin{array}{c}\text { IC50 }(\mu \mathrm{M}) \text { of Naphthoquinone Derivative Inhibiting Supercoiling Activity of } \\
\text { DNA Gyrase (Bacterial Topoisomerase II) Enzyme }\end{array}$} & Reference \\
\cline { 2 - 5 } & Diospyrin & 7-Methyljuglone & Menadione & Shinanolone \\
\hline Staphylococcus aureus & 8 & 60 & - & - \\
Escherichia coli & 4 & 30 & - & - \\
Mycobacterium tuberculosis & 15 & 30 & $>200$ & $>200$ \\
\hline
\end{tabular}

The ability of NQs to constrain the biological activity of topoisomerase enzyme plays a decisive role at the stage of cell duplication in bacteria (Figure 6). This approach would result in reducing the load of bacteria and their infections drastically. Rather than a direct killing (bactericidal) effect, the inhibition of topoisomerase enzyme activity can result in bacteriostatic action to prevent the growth of bacteria.

\section{Antifungal Potential of Naphthoquinones}

Currently, though numerous effective antifungal agents are accessible in the market, their toxicity, development of resistance etc. have been emerging issues in confronting fungal infections. The need for a groundbreaking antifungal agent is always a priority [42] In addition to antibacterial action, NQs also possess antifungal potential $[23,24,42]$. A study conducted by Carriço et al. [42] emphasized the potency of synthetic NQs against opportunistic and dermatophyte fungi. These fungi can grow on skin, nails, hair, feathers etc. where some of a body part surfaces and give rise to various diseases. Carriço et al. [42] assessed the antifungal activity of NQs against 89 fungal cultures. Among which, NQs, namely IVS320 (3a,10b-dihydro-1H-cyclopenta (b) naphtho (2,3-d) furan-5, 10-dione)-dione), IVS322 (7,9a-dihydro-6bH-cyclopenta (b) naphtho (2,1-d) furan-5,6-dione), nor- $\alpha$-lapachone (2,2-dimethyl-2,3-dihydronaphtho (2,3-b)furan-4, 9-dione) and nor- $\beta$ lapachone (2,2-dimethyl-2,3-dihydronaphtho (1,2-b) furan-4,5-dione), one NQ IVS320 (3a, $10 \mathrm{~b}$-dihydro- $1 \mathrm{H}$-cyclopenta $[\mathrm{b}]$ naphtho (2,3-d) furan-5,10-dione)-dione) demonstrated the lowest MIC against dermatophytes $(5-28 \mu \mathrm{g} / \mathrm{mL})$ and Cryptococcus spp. $(3-5 \mu \mathrm{g} / \mathrm{mL})$. A preliminary study smoothed to understand the mechanistic action of IVS320 in altering cell-membrane permeability and not the fungal cell wall. Likewise, thiolated NQ derivatives can also exhibit antifungal activity at a lower MIC. Recently, Wellington et al. [24] analyzed thiolated NQ derivatives against $C$. albicans and revealed the utmost activity with MIC of $23.4 \mu \mathrm{g} / \mathrm{mL}$. The authors further predicted that the removal of the metafluoro group from the same derivative can diminish its antifungal activity. SánchezCalvo et al. [19] demonstrated the antibacterial as well as antifungal activity of 1,4-NQs, 2-chloro-5,8-dihydroxy-1,4-NQ at the lowest MIC $(2 \mu \mathrm{g} / \mathrm{mL})$ against $C$. krusei. The antifungal properties of NQs along with antibacterial potential make them hopeful candidates for drug development.

The Boraginaceae family has been identified as one of the potential sources to isolate bioactive compounds having immense biological properties. Microbes associated with medicinal plants could also prove to be a potential resource to obtain bioactive molecules like NQs. This interesting concept has been presented by Mollaei et al. [105], where they used endophytic fungi associated with a medicinal plant (L. officinale of the Boraginaceae family) as a new source to extract shikonin. Such a study could prove an exceptional example to motivate the production of shikonin from endophytic fungi for industrial applications.

\section{Antiparasitic Potential of Naphthoquinones}

Along with antibacterial and antifungal activities, NQs are also recognized for antiparasitic activity $[106,107]$. Currently, parasitic diseases are a gigantic world-wide challenge for the medical sector [15]. Parasitic infections are receiving medical attention due to their severity. Salas et al. [21] documented that every year $\sim 15,000$ deaths occur due to the 
infection caused by the parasite Trypanosoma cruzi. This clinical condition is known as Chagas disease. Naturally occurring NQs, viz. lapachol, $\beta$-lapachone, and its $\alpha$-isomer have prevalent trypanocidal potential. For antiparasitic drug development, NQs seem to be a suitable class of chemicals [108]. These researchers have reported not only the synthesis but also the antiparasitic activity of semisynthetic NQs (similar to isolapachol). These semisynthetic NQs have comparatively better antimalarial potential than lapachol when they were tested against Plasmodium falciparum. Salas et al. [21] also described the molecular mechanism, commenting that the compound represses the formation of hemozoin crystals in parasites when they were treated with NQs. Thus, NQs inhibit the b-hematin polymerization process in P. falciparum. Bis-NQ derivatives also exhibit antiparasitic activities against Toxoplasma gondii and T. brucei [22]. The antiparasitic activities of NQs is another fascinating approach to explore NQs in the field of medicinal chemistry.

\section{Future Prospects}

The versatile nature of NQs (biological and chemical) has been explored as an emerging warrior in the battle against microbial pathogens. Even though several limitations and challenges are associated in the current area of research, we need to uplift these dynamic molecules as superlative opportunities to achieve our breakthrough. There are many more unexplored natural sources (plants, animals, microorganisms, etc.) that can be utilized to extract diverse types of NQs. The Boraginaceae family representing 2000 sp. (trees, shrubs, herbs) are present ubiquitously and act as a potential source of bioactive compounds for medical applications. Microorganisms associated with medicinal plants could also prove to be a potential resource to extract NQs. NQ entities possess unique spatial configurations that enable substitution, addition, and modification/alteration. Even though various organic solvents are used to extract NQs from plant material, it is important to note that the selection of an appropriate solvent is crucial in order to enhance quality. Therefore, conscious efforts would facilitate the improvement of the overall yield of NQs from the chosen natural sources.

In the scientific community, 1,4-NQs are esteemed in comparison to 1,2-NQs and are therefore available as another entity to explore. We admire the tremendous work reported on the synthesis of several NQ derivatives along with their functional properties through MIC and $\mathrm{IC}_{50}$ based assays. However, only sparse information discusses the mechanistic role of NQs in the biological system. Looking at the literature, we strongly feel that there are some weaknesses associated with the research being carried out on the analysis of functional activities of NQ derivatives against several pathogens. The main hindrance to perform those techniques is the requirement of highly sophisticated microscopic facilities. Subsequent improvement in this area would accelerate focused applications of the available therapeutic compounds. Information regarding the identification of the exact molecular target of NQs is deficient. From the ESKAPE and MDR groups, Staphylococcus spp. (Grampositive) has been successfully inhibited in the presence of both natural and chemically modified NQs. Thorough knowledge of the mechanistic approaches of NQs against Gramnegative organisms belonging to the ESKAPE and MDR categories would be feasible. The multifunctional potentiality of NQs can be utilized solely, synergistically, or in combination. The combination of NQs with antibiotics and nanoparticles are hopeful strategies to combat pathogens. Extensive in vitro and in vivo analysis along with successful clinical trials are necessary. Like antimicrobial strategies, cancer therapy is one of the leading and challenging fields of medicinal biology. Several NQs display distinctive cytotoxic properties, as well as anticancer potential, as observed in different cell lines like adeno, breast, colon, lung carcinoma etc. The development of novel anticancer agents is the topmost priority for the healthcare system. Most cancers are not controllable using radiotherapy and surgical means. Therefore, chemotherapeutic agents involving pioneering small molecules are in the spotlight of cancer biology research. Interestingly, NQs are widely explored and the foremost focus for therapeutic purposes. Commercially, several quinone-based anticancer agents like bleomycins, dactinomycin, daunorubicin, doxorubicin, idarubicin, 
mitoxantrone, and mitomycin-C are in use. Similarly, NQs impose effects on multiple singling pathways in tumor cells, through interfering in the cell-division cycle, DNA topoisomerases, and kinase signaling. Thus, there is a need for new-fangled molecules like NQs to treat cancer. The targeted drug synthesis can be achieved by considering the specific site of action of NQs in a biological system. This approach can be supplemented through valuable inputs using molecular docking analysis at the preliminary stage. The molecular docking perspective assuredly opens broad avenues to understanding the interactions of chemical entities at the molecular level. Computational modeling also offers a supportive role to predict the functionality of compounds in a complex system. These approaches would precisely lead us to develop effective or perhaps the most potent drugs for the medical sector.

\section{Conclusions}

Naphthoquinones, especially 1,4-NQs, stand as multifunctional molecules due to their extraordinary potential to inhibit bacteria, fungi, parasites, and cancer. It is also remarkable to note that the mechanism of action for each NQ molecule might differ. This could be possible chiefly because of the SAR and variation in the target sites. The addition or removal of a specific group from NQs largely affects its activity against pathogens. Curing of plasmids, production of ROS, inhibition of EPs, and topoisomerase enzymes remain the leading causes of NQs as antibacterial agents. Gram-positive pathogens are susceptible targets for NQs. Staphylococcus spp.-representative bacterium of the ESKAPE and MDR pathogen groups-has been frequently reported for naturally occurring $(\sim 20 \%)$ and chemically synthesized 1,4-NQs ( 27\%). Followed by Staphylococcus spp., Bacillus spp. $(\sim 16 \%)$ has been seen to be another susceptible target for naturally occurring $1,4-$ NQs. From Gram-negative bacterial genera, E. coli $(\sim 11 \%)$ and Pseudomonas spp. ( 9\%) have been identified as a vulnerable target. Additionally, researchers have used several other microbial pathogens to conduct laboratory experiments. The ability of NQs to cure plasmids and cause the inhibition of EPs could be a wise approach for combinatorial or synergistic therapies. Overall, the multifunctional potential of NQs and their derivatives present them as a future molecule of medicinal chemistry. Powerful evidence about the mechanistic approaches of emerging trends like NQs could be a hopeful milestone to defeat the battle against microbial pathogens.

Note: Chemical structures were designed using ChemDraw software (12, PerkinElmer, Waltham, MA, USA). Based on information available in the literature, all figures have been constructed using Paint 3D (6.2009.30067.0, Microsoft Lift London, Redmond, WA, USA) and BioRender (Professional Science Figure creator, BioRender, Toronto, ON, Canada) applications.

Author Contributions: S.K.S. and N.N.N., designed the concept. N.S.M., D.S., R.H.P. and S.A.B. collected essential literature and designed all figures. M.C. contributed towards chemical structure design using software. P.Z. guided the therapeutic approach of naphthoquinone derivatives. All authors have contributed towards executing those ideas and writing the manuscript. Finally, All authors have read and agreed to the published version of the manuscript.

Funding: S.K.S. express a deep sense of gratitude towards the Department of Science and Technology (DST), Govt. of India for financial support. (Ref: EMR/2016/007912). S.K.S. also expresses special thanks to Rashtriya Uchchatar Shiksha Abhiyan (Ref: RUSA-CBS-TH-3.2) for financial support. NNN acknowledges the financial support from Dnyandeo Yashwantrao Patil Vidyapeeth, Pune (Ref: DPU/755(8)/2017).

Institutional Review Board Statement: Not applicable.

Informed Consent Statement: Not applicable.

Data Availability Statement: This is a review article, and the entire data is presented within the article.

Acknowledgments: Not applicable.

Conflicts of Interest: The authors declare no conflict of interest. 


\begin{abstract}
Abbreviations
NQ, naphthoquinones; ROS, reactive oxygen species; WHO, world health organization; AMR, Antimicrobial resistance; MDR, multidrug-resistance; MIC, minimum inhibitory concentration; MBC, minimum bactericidal concentrations; SAR, structure-activity relationship; EPs, efflux pumps; MRSA, methicillin-resistant Staphylococcus aureus; MSSA, methicillin-sensitive Staphylococcus aureus; DMSO, dimethyl sulfoxide; IPA, isopropyl alcohol; ACN, acetonitrile; DMF, dimethyl formamide; DmsD: TaT proofreading chaperon $\mathrm{D}$, iTRAQ, Isobaric tags for relative and absolute quantitation. tyrosyl-tRNA synthetase (TyrRS) inhibitor; EtBr, Ethidium bromide; AO, acridine orange; AF, acriflavine; SDS, sodium dodecyl sulphate; RND, resistance- nodulation-division; SMR, small multidrug resistance; MFS, major facilitator superfamily; MATE, multidrug and toxic compound extrusion; ABC, adenosine triphosphate (ATP) binding cassette.
\end{abstract}

\title{
References
}

1. Gaynes, R. The discovery of Penicillin-New insights after more than 75 years of clinical use. Emerg. Infect. Dis. 2017, 23, 849-853. [CrossRef]

2. Horner, W.H. Streptomycin. In Biosynthesis; Springer: Berlin/Heidelberg, Germany, 1967; pp. 373-399.

3. Global Pharma News and Resources. Available online: https://www.pharmiweb.com/press-release/2020-07-02/globalantibiotics-market-is-expected-to-reach-at-a-cagr-of-47-during-the-forecast-period-2019-202 (accessed on 8 September 2020).

4. Tacconelli, E.; Carrara, E.; Savoldi, A.; Harbarth, S.; Mendelson, M.; Monnet, D.L.; Pulcini, C.; Kahlmeter, G.; Kluytmans, J.; Carmeli, Y.; et al. Discovery, research, and development of new antibiotics: The WHO priority list of antibiotic-resistant bacteria and tuberculosis. Lancet Infect. Dis. 2018, 18, 318-327. [CrossRef]

5. Mulani, M.S.; Kamble, E.E.; Kumkar, S.N.; Tawre, M.S.; Pardesi, K.R. Emerging strategies to combat ESKAPE pathogens in the era of antimicrobial resistance: A review. Front. Microbiol. 2019, 10, 1-24. [CrossRef] [PubMed]

6. Tanwar, J.; Das, S.; Fatima, Z.; Hameed, S. Multidrug resistance: An emerging crisis. Interdiscip. Perspect. Infect. Dis. 2014, 2014, 541340. [CrossRef] [PubMed]

7. De Oliveira, D.M.P.; Forde, B.M.; Kidd, T.J.; Harris, P.N.; Schembri, M.A.; Beatson, S.A.; Paterson, D.L.; Walker, M.J. Antimicrobial resistance in ESKAPE pathogens. Clin. Microbiol. Rev. 2020, 33, e00181-19. [CrossRef] [PubMed]

8. Rice, L.B. Federal funding for the study of antimicrobial resistance in nosocomial pathogens: No ESKAPE. J. Infect. Dis. 2008, 197, 1079-1081. [CrossRef] [PubMed]

9. World Health Organization. Available online: https://www.who.int/medicines/publications/WHO-PPL-Short_Summary_25 Feb-ET_NM_WHO.pdf?ua=1 (accessed on 10 November 2020).

10. World Health Organization. Available online: https://www.who.int/news-room/events/detail/2020/11/18/default-calendar/ world-antimicrobial-awareness-week-2020 (accessed on 16 November 2020).

11. Nikaido, H. Multidrug resistance in bacteria. Annu. Rev. Biochem. 2009, 78, 119-146. [CrossRef] [PubMed]

12. Santajit, S.; Indrawattana, N. Mechanisms of antimicrobial resistance in ESKAPE pathogens. BioMed Res. Int. 2016, $2016,475067$. [CrossRef] [PubMed]

13. Sharifi-Rad, J.; Salehi, B.; Stojanović-Radić, Z.Z.; Fokou, P.V.T.; Sharifi-Rad, M.; Mahady, G.B.; Sharifi-Rad, M.; Masjedi, M.-R.; Lawal, T.O.; Ayatollahi, S.A.; et al. Medicinal plants used in the treatment of tuberculosis-ethnobotanical and ethnopharmacological approaches. Biotechnol. Adv. 2020, 44, 107629. [CrossRef] [PubMed]

14. Tiwari Pandey, A.; Pandey, I.; Hachenberger, Y.; Krause, B.C.; Haidar, R.; Laux, P.; Luch, A.; Singh, M.P.; Singh, A.V. Emerging paradigm against global antimicrobial resistance via bioprospecting of mushroom into novel nanotherapeutics development. Trends Food Sci. Technol. 2020, 106, 333-344. [CrossRef]

15. Tiwari Pandey, A.; Pandey, I.; Zamboni, P.; Gemmati, D.; Kanase, A.; Singh, A.V.; Singh, M.P. Traditional herbal remedies with a multifunctional therapeutic approach as an implication in COVID-19 associated co-infections. Coatings 2020, 10, 761. [CrossRef]

16. Ansari, M.H.D.; Lavhale, S.; Kalunke, R.M.; Srivastava, P.L.; Pandit, V.; Gade, S.; Yadav, S.; Laux, P.; Luch, A.; Gemmati, D.; et al. Recent advances in plant nanobionics and nanobiosensors for toxicology applications. Curr. Nanosci. 2020, 16, 27-41. [CrossRef]

17. Singh, V.; Kumar, V.; Kashyap, S.; Singh, A.V.; Kishore, V.; Sitti, M.; Saxena, P.S.; Srivastava, A. Graphene oxide synergistically enhances antibiotic efficacy in vancomycin-resistant Staphylococcus aureus. ACS Appl. Bio Mater. 2019, 2, 1148-1157. [CrossRef]

18. Kurban, S.; Deniz, N.G.; Sayil, C.; Ozyurek, M.; Guclu, K.; Stasevych, M.; Zvarych, V.; Komarovska-Porokhnyavet, O.; Novikov, V. Synthesis, antimicrobial properties, and inhibition of catalase activity of 1,4-naphtho-and benzoquinone derivatives containing N-, S-, O-substituted. Heteroat. Chem. 2019, 2019, 1658417. [CrossRef]

19. Sánchez-Calvo, J.M.; Barbero, G.R.; Guerrero-Vásquez, G.; Durán, A.G.; Macías, M.; Rodríguez-Iglesias, M.A.; Molinillo, J.M.; Macías, F.A. Synthesis, antibacterial and antifungal activities of naphthoquinone derivatives: A structure-activity relationship study. Med. Chem. Res. 2016, 25, 1274-1285. [CrossRef]

20. Mathiyazhagan, K.; Kumaran, A.; Arjun, P. Isolation of natural naphthoquinones from Juglans regia and in vitro antioxidant and cytotoxic studies of naphthoquinones and the synthetic naphthofuran derivatives. Russ. J. Bioorganic Chem. 2018, 44, 346-353. [CrossRef] 
21. Salas, C.O.; Faúndez, M.; Morello, A.; Diego Maya, J.A.; Tapia, R. Natural and synthetic naphthoquinones active against Trypanosoma Cruzi: An initial step towards new drugs for Chagas disease. Curr. Med. Chem. 2011, 18, 144-161. [CrossRef] [PubMed]

22. Jentzsch, J.; Koko, W.S.; Al Nasr, I.S.; Khan, T.A.; Schobert, R.; Ersfeld, K.; Biersack, B. New antiparasitic bis-naphthoquinone derivatives. Chem. Biodivers. 2020, 17, e1900597. [CrossRef] [PubMed]

23. Lall, N.; Weiganand, O.; Hussein, A.A.; Meyer, J.J.M. Antifungal activity of naphthoquinones and triterpenes isolated from the root bark of Euclea natalensis. South Afr. J. Bot. 2006, 72, 579-583. [CrossRef]

24. Wellington, K.W.; Nyoka, N.B.; McGaw, L.J. Investigation of the antibacterial and antifungal activity of thiolated naphthoquinones. Drug Dev. Res. 2019, 80, 386-394. [CrossRef] [PubMed]

25. Tandon, V.K.; Singh, R.V.; Yadav, D.B. Synthesis and evaluation of novel 1,4-naphthoquinone derivatives as antiviral, antifungal and anticancer agents. Bioorg. Med. Chem. Lett. 2004, 14, 2901-2904. [CrossRef] [PubMed]

26. Schuck, D.C.; Ferreira, S.B.; Cruz, L.N.; Da Rocha, D.R.; Moraes, M.S.; Nakabashi, M.; Rosenthal, P.J.; Ferreira, V.F.; Garcia, C.R. Biological evaluation of hydroxynaphthoquinones as anti-malarials. Malar. J. 2013, 12, 1-6. [CrossRef] [PubMed]

27. Klaus, V.; Hartmann, T.; Gambini, J.; Graf, P.; Stahl, W.; Hartwig, A.; Klotz, L.-O. 1,4-Naphthoquinones as inducers of oxidative damage and stress signaling in HaCaT human keratinocytes. Arch. Biochem. Biophys. 2010, 496, 93-100. [CrossRef] [PubMed]

28. Liang, W.; Cai, A.; Chen, G.; Xi, H.; Wu, X.; Cui, J.; Zhang, K.; Zhao, X.; Yu, J.; Wei, B.; et al. Shikonin induces mitochondriamediated apoptosis and enhances chemotherapeutic sensitivity of gastric cancer through reactive oxygen species. Sci. Rep. 2016, 6, 38267. [CrossRef] [PubMed]

29. Liu, C.; Shen, G.N.; Luo, Y.H.; Piao, X.J.; Jiang, X.Y.; Meng, L.Q.; Wang, Y.; Zhang, Y.; Wang, J.R.; Wang, H.; et al. Novel 1,4-naphthoquinone derivatives induce apoptosis via ROS-mediated P38/MAPK, Akt and STAT3 signaling in human hepatoma Hep3B cells. Int. J. Biochem. Cell Biol. 2018, 96, 9-19. [CrossRef] [PubMed]

30. Lim, M.-Y.; Jeon, J.-H.; Jeong, E.-Y.; Lee, C.-H.; Lee, H.-S. Antimicrobial activity of 5-hydroxy-1,4-naphthoquinone isolated from Caesalpinia sappan toward intestinal bacteria. Food Chem. 2007, 100, 1254-1258. [CrossRef]

31. Periasamy, H.; Iswarya, S.; Pavithra, N.; Senthilnathan, S.; Gnanamani, A. In vitro antibacterial activity of plumbagin isolated from Plumbago zeylanica L. against methicillin-resistant Staphylococcus aureus. Lett. Appl. Microbiol. 2019, 69, 41-49. [CrossRef] [PubMed]

32. Patwardhan, R.B.; Shinde, P.S.; Chavan, K.R.; Devale, A. Reversal of plasmid encoded antibiotic resistance from nosocomial pathogens by using Plumbago auriculata root extracts. Int. J. Curr. Microbiol. Appl. Sci. 2015, 2, 187-198.

33. Kaewbumrung, S.; Panichayupakaranant, P. Antibacterial activity of plumbagin derivative-rich Plumbago indica root extracts and chemical stability. Nat. Prod. Res. 2014, 28, 835-837. [CrossRef] [PubMed]

34. Patwardhan, R.B.; Dhakephalkar, P.K.; Chopade, B.A.; Dhavale, D.D.; Bhonde, R.R. Purification and characterization of an active principle, lawsone, responsible for the plasmid curing activity of Plumbago zeylanica root extracts. Front. Microbiol. 2018, 9, 2618. [CrossRef] [PubMed]

35. Tekin, V.; Muftuler, F.Z.B.; Guldu, O.K.; Kilcar, A.Y.; Medine, E.I.; Yavuz, M.; Unak, P.; Timur, S. Biological affinity evaluation of Lawsonia inermis origin lawsone compound and its radioiodinated form via in vitro methods. J. Radioanal. Nucl. Chem. 2015, 303, 701-708. [CrossRef]

36. Huang, X.Y.; Fu, H.L.; Tang, H.Q.; Yin, Z.Q.; Zhang, W.; Shu, G.; Yin, L.Z.; Zhao, L.; Yan, X.R.; Lin, J.C. Optimization extraction of shikonin using ultrasound-assisted response surface methodology and antibacterial studies. Evid. Based Complement Alternat. Med. 2020, 2020, 1-4. [CrossRef] [PubMed]

37. Lee, Y.S.; Lee, D.Y.; Kim, Y.B.; Lee, S.W.; Cha, S.W.; Park, H.W.; Kim, G.S.; Kwon, D.Y.; Lee, M.H.; Han, S.H. The mechanism underlying the antibacterial activity of shikonin against methicillin-resistant Staphylococcus aureus. Evid. Based Complement Alternat. Med. 2015, 2015, 520578. [CrossRef]

38. Zani, C.L.; De Oliveira, A.B.; De Oliviera, G.G. Furanonaphthoquinones from Tabebuia Ochracea. Phytochemistry 1991, 30, 2379-2381. [CrossRef]

39. Souza, M.A.; Johann, S.; Lima, L.A.R.d.S.; Campos, F.F.; Mendes, I.C.; Beraldo, H.; Souza-Fagundes, E.M.d.; Cisalpino, P.S.; Rosa, C.A.; Alves, T.M.d.A.; et al. The antimicrobial activity of lapachol and its thiosemicarbazone and semicarbazone derivatives. Mem. Inst. Oswaldo Cruz. 2013, 108, 342-351. [CrossRef]

40. Widhalm, J.R.; Rhodes, D. Biosynthesis and molecular actions of specialized 1,4-naphthoquinone natural products produced by horticultural plants. Hortic. Res. 2016, 3, 1-17. [CrossRef] [PubMed]

41. Zhou, D.-Y.; Zhu, B.-W.; Wang, X.-D.; Qin, L.; Li, D.-M.; Miao, L.; Murata, Y. Stability of polyhydroxylated 1,4-naphthoquinone pigment recovered from spines of sea urchin Strongylocentrotus nudus. Int. J. Food Sci. Technol. 2012, 47, 1479-1486. [CrossRef]

42. Carriço, M.d.P.S.B.; do Carmo Cardoso, M.F.; Da Silva, F.D.C.; Ferreira, V.F.; Lima, E.S.; Souza, J.V.B. Antifungal activity of synthetic naphthoquinones against dermatophytes and opportunistic fungi: Preliminary mechanism-of-action tests. Ann. Clin. Microbiol. Antimicrob. 2014, 13, 26.

43. Adusei, E.; Adosraku, R.K.; Oppong-Kyekyeku, J.; Amengor, C.D.; Jibira, Y. Resistance modulation action, time-kill kinetics assay, and inhibition of biofilm formation effects of plumbagin from Plumbago zeylanica Linn. J. Trop. Med. 2019, 2019, 31. [CrossRef]

44. Vukic, M.D.; Vukovic, N.L.; Djelic, G.T.; Popovic, S.L.; Zaric, M.M.; Baskic, D.D.; Krstic, G.B.; Tesevic, V.V.; Kacaniova, M.M. Antibacterial and cytotoxic activities of naphthoquinone pigments from Onosma visianii Clem. EXCLI J. 2017, 16, 73-88. [PubMed]

45. Petrosyan, M.; Shcherbakova, Y.; Sahakyan, N.; Vardanyan, Z.; Poladyan, A.; Popov, Y.; Trchounian, A. Alkanna orientalis (L.) Boiss. Plant isolated cultures and antimicrobial activity of their extracts: Phenomenon, dependence on different factors and effects on some membrane-associated properties of bacteria. Plant Cell Tissue Organ Cult. 2015, 122, 727-738. [CrossRef] 
46. Wang, J.; Cheng, Y.; Wu, R.; Jiang, D.; Bai, B.; Tan, D.; Yan, T.; Sun, X.; Zhang, Q.; Wu, Z. Antibacterial activity of juglone against Staphylococcus aureus: From apparent to proteomic. Int. J. Mol. Sci. 2016, 17, 965. [CrossRef] [PubMed]

47. Padhye, S.; Dandawate, P.; Yusufi, M.; Ahmad, A.; Sarkar, F.H. Perspectives on medicinal properties of plumbagin and its analogs. Med. Res. Rev. 2012, 32, 1131-1158. [CrossRef] [PubMed]

48. Al-Mussawi, A.A. Isolation and identification of shikonin from Arnebia Decumbens L. and its antibacterial activity. Res. J. Appl. Sci. 2010, 6, 1452-1456.

49. Andújar, I.; Ríos, J.L.; Giner, R.M.; Recio, M.C. Pharmacological properties of shikonin-a review of literature since 2002. Planta Med. 2013, 79, 1685-1697. [CrossRef]

50. Aljanaby, A.J. Antibacterial Activity of an aqueous extracts of Alkanna tinctoria roots against drug resistant aerobic pathogenic bacteria isolated from patients with burns infections. Russ. Open Med. J. 2018, 7, e0104. [CrossRef]

51. De Almeida, E.R. Preclinical and clinical studies of lapachol and beta-lapachone. Open Nat. Prod. J. 2009, 2, 42-47. [CrossRef]

52. Balachandran, C.; Al-Dhabi, N.A.; Duraipandiyan, V.; Ignacimuthu, S. Bluemomycin, a new naphthoquinone derivative from Streptomyces sp. with antimicrobial and cytotoxic properties. Biotechnol. Lett. 2021, 43, 1-4.

53. Ravichandiran, P.; Sheet, S.; Premnath, D.; Kim, A.R.; Yoo, D.J. 1,4-Naphthoquinone analogues: Potent antibacterial agents and mode of action evaluation. Molecules 2019, 24, 1437. [CrossRef] [PubMed]

54. Tandon, V.K.; Yadav, D.B.; Singh, R.V.; Chaturvedi, A.K.; Shukla, P.K. Synthesis and biological evaluation of novel (L)- $\alpha$-amino acid methyl ester, heteroalkyl, and aryl substituted 1,4-naphthoquinone derivatives as antifungal and antibacterial agents. Bioorg. Med. Chem. Lett. 2005, 15, 5324-5328. [CrossRef] [PubMed]

55. Yap, J.K.Y.; Tan, S.Y.Y.; Tang, S.Q.; Thien, V.K.; Chan, E.W.L. Synergistic antibacterial activity between 1,4-naphthoquinone and $\beta$ lactam antibiotics against methicillin-resistant Staphylococcus aureus. Microb. Drug Resist. 2021, 27, 234-240. [CrossRef] [PubMed]

56. Sarkar, A.; Ghosh, S.; Shaw, R.; Patra, M.M.; Calcuttawala, F.; Mukherjee, N.; Gupta, S.K.D. Mycobacterium tuberculosis thymidylate synthase (ThyX) is a target for plumbagin, a natural product with antimycobacterial activity. PLoS ONE 2020, 15, e0228657. [CrossRef] [PubMed]

57. Meah, M.S.; Lertcanawanichakul, M.; Pedpradab, P.; Lin, W.; Zhu, K.; Li, G.; Panichayupakaranant, P. Synergistic effect on anti-methicillin-resistant Staphylococcus aureus among combinations of $\alpha$-mangostin-rich extract, lawsone methyl ether and ampicillin. Lett. Appl. Microbiol. 2020, 71, 510-519. [CrossRef] [PubMed]

58. Song, R.; Yu, B.; Friedrich, D.; Li, J.; Shen, H.; Krautscheid, H.; Huang, S.D.; Kim, M.-H. Naphthoquinone-derivative as a synthetic compound to overcome the antibiotic resistance of methicillin-resistant S. aureus. Commun. Biol. 2020, 3 , 1-11. [CrossRef] [PubMed]

59. Linzner, N.; Fritsch, V.N.; Busche, T.; Tung, Q.N.; Loi, V.V.; Bernhardt, J.; Kalinowski, J.; Antelmann, H. The plant-derived naphthoquinone lapachol causes an oxidative stress response in Staphylococcus aureus. Free Radic. Biol. Med. 2020, 158, 126-136. [CrossRef]

60. Figueredo, F.G.; Ramos, I.T.L.; Paz, J.A.; Silva, T.M.S.; Camara, C.A.; Oliveira-Tintino, C.D.d.M.; Relison Tintino, S.; de Farias, P.A.M.; Coutinho, H.D.M.; Fonteles, M.M.d.F. In silico evaluation of the antibacterial and modulatory activity of lapachol and nor-lapachol derivates. Microb. Pathog. 2020, 144, 104181. [CrossRef]

61. Choudhari, D.; Salunke-Gawali, S.; Chakravarty, D.; Shaikh, S.R.; Lande, D.N.; Gejji, S.P.; Rao, P.K.; Satpute, S.; Puranik, V.G.; Gonnade, R. Synthesis and biological activity of imidazole based 1,4-naphthoquinones. New J. Chem. 2020, 44, 6889-6901. [CrossRef]

62. Choudhari, D.; Chakravarty, D.; Lande, D.N.; Parveen, S.; Gejji, S.P.; Kodam, K.M.; Salunke-Gawali, S. Crystal structures and biological activity of homologated (N)-n-alkylammonium salts of 2-bromo-3-oxido-1,4-naphthoquinone. Struct. Chem. 2019, 30, 2257-2270. [CrossRef]

63. Andrade, J.C.; Morais Braga, M.F.B.; Guedes, G.M.M.; Tintino, S.R.; Freitas, M.A.; Quintans, L.J.; Menezes, I.R.A.; Coutinho, H.D.M. Menadione (vitamin K) enhances the antibiotic activity of drugs by cell membrane permeabilization mechanism. Saudi J. Biol. Sci. 2017, 24, 59-64. [CrossRef] [PubMed]

64. Moreira, C.S.; Silva, A.; Novais, J.S.; Sá Figueiredo, A.M.; Ferreira, V.F.; da Rocha, D.R.; Castro, H.C. Searching for a potential antibacterial lead structure against bacterial biofilms among new naphthoquinone compounds. J. Appl. Microbiol. 2017, 122, 651-662. [CrossRef] [PubMed]

65. Janeczko, M.; Demchuk, O.M.; Strzelecka, D.; Kubiński, K.; Masłyk, M. New family of antimicrobial agents derived from 1,4-naphthoquinone. Eur. J. Med. Chem. 2016, 124, 1019-1025. [CrossRef] [PubMed]

66. Qiu, H.Y.; Wang, P.F.; Wang, Z.Z.; Luo, Y.L.; Hu, D.Q.; Qi, J.L.; Lu, G.H.; Pang, Y.J.; Yang, R.W.; Zhu, H.L.; et al. Shikonin derivatives as inhibitors of tyrosyl-TRNA synthetase: Design, synthesis and biological evaluation. RSC Adv. 2016, 6, 83003-83010. [CrossRef]

67. Zmantar, T.; Miladi, H.; Kouidhi, B.; Chaabouni, Y.; Slama, R.B.; Bakhrouf, A.; Mahdouani, K.; Chaieb, K. Use of juglone as antibacterial and potential efflux pump inhibitors in Staphylococcus aureus isolated from the oral cavity. Microb. Pathog. 2016, 101, 44-49. [CrossRef] [PubMed]

68. Ravichandiran, P.; Premnath, D.; Vasanthkumar, S. Synthesis, molecular docking and antibacterial evaluation of 2-(4-(4aminophenylsulfonyl) phenylamino)-3-(thiophen-2-ylthio) naphthalene-1,4-dione derivatives. Front. Chem. Sci. Eng. 2015, 9, 46-56. [CrossRef] 
69. Sreelatha, T.; Kandhasamy, S.; Dinesh, R.; Shruthy, S.; Shweta, S.; Mukesh, D.; Karunagaran, D.; Balaji, R.; Mathivanan, N.; Perumal, P.T. Synthesis and sar study of novel anticancer and antimicrobial naphthoquinone amide derivatives. Bioorg. Med. Chem. Lett. 2014, 24, 3647-3651. [CrossRef]

70. Schlievert, P.M.; Merriman, J.A.; Salgado-Pabón, W.; Mueller, E.A.; Spaulding, A.R.; Vu, B.G.; Chuang-Smith, O.N.; Kohler, P.L.; Kirby, J.R. Menaquinone analogs inhibit growth of bacterial pathogens. Antimicrob. Agents Chemother. 2013, 57, $5432-5437$. [CrossRef] [PubMed]

71. Rahmoun, N.M.; Boucherit-Otmani, Z.; Boucherit, K.; Benabdallah, M.; Villemin, D.; Choukchou-Braham, N. Antibacterial and antifungal activity of lawsone and novel naphthoquinone derivatives. Med. Mal. Infect. 2012, 42, 270-275. [CrossRef]

72. Mathew, R.; Kruthiventi, A.K.; Prasad, J.V.; Kumar, S.P.; Srinu, G.; Chatterji, D. Inhibition of mycobacterial growth by plumbagin derivatives. Chem. Biol. Drug Des. 2010, 76, 34-42. [CrossRef] [PubMed]

73. Tandon, V.K.; Maurya, H.K.; Mishra, N.N.; Shukla, P.K. Design, synthesis and biological evaluation of novel nitrogen and sulfur containing hetero-1,4-naphthoquinones as potent antifungal and antibacterial agents. Eur. J. Med. Chem. 2009, 44, 3130-3137. [CrossRef] [PubMed]

74. Medina, L.F.C.; Hertz, P.F.; Stefani, V.; Henriques, J.A.P.; Zanotto-Filho, A.; Brandelli, A. Aminonaphthoquinone induces oxidative stress in Staphylococcus aureus. Biochem. Cell Biol. 2006, 84, 720-727. [CrossRef] [PubMed]

75. Singh, A.V.; Ansari, M.H.D.; Rosenkranz, D.; Maharjan, R.S.; Kriegel, F.L.; Gandhi, K.; Kanase, A.; Singh, R.; Laux, P.; Luch, A. Artificial intelligence and machine learning in computational nanotoxicology: Unlocking and empowering nanomedicine. Adv. Healthc. Mater. 2020, 9, 1901862. [CrossRef]

76. Singh, A.V.; Rosenkranz, D.; Ansari, M.H.D.; Singh, R.; Kanase, A.; Singh, S.P.; Blair, J.; Jutta, T.; Laux, P.; Luch, A. Artificial intelligence and machine learning empower advanced biomedical material design to toxicity prediction. Adv. Intell. Syst. 2020, 2, 2000084. [CrossRef]

77. Singh, A.V.; Maharjan, R.-S.; Kanase, A.; Siewert, K.; Rosenkranz, D.; Singh, R.; Laux, P.; Luch, A. Machine-learning-based approach to decode the influence of nanomaterial properties on their interaction with cells. ACS Appl. Mater. Interfaces 2021, 13, 1943-1955. [CrossRef] [PubMed]

78. Figueredo, F.G.; Ramos, I.T.; Paz, J.A.; Silva, T.M.; Câmara, C.A.; de Morais Oliveira-Tintino, C.D.; Tintino, S.R.; de Farias, P.A.M.; de Menezes, I.R.A.; Coutinho, H.D.M.; et al. Effect of hydroxyamines derived from lapachol and norlachol against Staphylococcus aureus strains carrying the NorA efflux pump. Infect. Genet. Evol. 2020, 84, 104370. [CrossRef]

79. Klotz, L.O.; Hou, X.; Jacob, C. 1,4-Naphthoquinones: From oxidative damage to cellular and inter-cellular signaling. Molecules 2014, 19, 14902-14918. [CrossRef]

80. Lee, M.H.; Lapidus, R.G.; Ferraris, D.; Emadi, A. Analysis of the mechanisms of action of naphthoquinone-based anti-acute myeloid leukemia chemotherapeutics. Molecules 2019, 24, 3121. [CrossRef] [PubMed]

81. Pereyra, C.E.; Dantas, R.F.; Ferreira, S.B.; Gomes, L.P.; Silva, F.P., Jr. The diverse mechanisms and anticancer potential of naphthoquinones. Cancer Cell Int. 2019, 19, 1-20. [CrossRef] [PubMed]

82. Shintani, M.; Sanchez, Z.K.; Kimbara, K. Genomics of microbial plasmids: Classification and identification based on replication and transfer systems and host taxonomy. Front. Microbiol. 2015, 6, 242. [CrossRef] [PubMed]

83. Okpokwasili, G.C.; Somerville, C.C.; Sullivan, M.; Grimes, D.J.; Colwell, R.R. Plasmid mediated degradation of hydrocarbons in estuarine bacteria. Oil Chem. Pollut. 1986, 3, 117-129. [CrossRef]

84. Campelo, A.B.; Gaspar, P.; Roces, C.; Rodríguez, A.; Kok, J.; Kuipers, O.P.; Neves, A.R.; Martínez, B. The Lcn972 bacteriocinencoding plasmid PBL1 impairs cellobiose metabolism in Lactococcus lactis. Appl. Environ. Microbiol. 2011, 77, 7576-7585. [CrossRef] [PubMed]

85. Buckner, M.M.; Ciusa, M.L.; Piddock, L.J. Strategies to combat antimicrobial resistance: Anti-plasmid and plasmid curing. FEMS Microbiol. Rev. 2018, 42, 781-804. [CrossRef] [PubMed]

86. Letchumanan, V.; Chan, K.-G.; Lee, L.-H. An insight of traditional plasmid curing in vibrio species. Front. Microbiol. 2015, 6, 735. [CrossRef] [PubMed]

87. Lakshmi, V.V.; Thomas, C.M. Curing of F-like plasmid TP181 by plumbagin is due to interference with both replication and maintenance functions. Microbiology 1996, 142, 2399-2406. [CrossRef]

88. Beg, A.Z.; Ahmad, I. Effect of Plumbago zeylanica extract and certain curing agents on multidrug resistant bacteria of clinical origin. World J. Microbiol. Biotechnol. 2000, 16, 841-844. [CrossRef]

89. Masi, M.; Réfregiers, M.; Pos, K.M.; Pagès, J.-M. Mechanisms of envelope permeability and antibiotic influx and efflux in gram-negative bacteria. Nat. Microbiol. 2017, 2, 1-7. [CrossRef] [PubMed]

90. Shriram, V.; Khare, T.; Bhagwat, R.; Shukla, R.; Kumar, V. Inhibiting bacterial drug efflux pumps via phyto-therapeutics to combat threatening antimicrobial resistance. Front. Microbiol. 2018, 9, 2990. [CrossRef] [PubMed]

91. Blanco, P.; Hernando-Amado, S.; Reales-Calderon, J.A.; Corona, F.; Lira, F.; Alcalde-Rico, M.; Bernardini, A.; Sanchez, M.B.; Martinez, J.L. Bacterial multidrug efflux pumps: Much more than antibiotic resistance determinants. Microorganisms 2016, 4, 14. [CrossRef]

92. Kumar, A.; Khan, I.A.; Koul, S.; Koul, J.L.; Taneja, S.C.; Ali, I.; Ali, F.; Sharma, S.; Mirza, Z.M.; Kumar, M.; et al. Novel structural analogues of piperine as inhibitors of the NorA efflux pump of Staphylococcus aureus. J. Antimicrob. Chemother. 2008, 61, 1270-1276. [CrossRef] 
93. Stermitz, F.R.; Tawara-Matsuda, J.; Lorenz, P.; Mueller, P.; Zenewicz, L.; Lewis, K. 5'-Methoxyhydnocarpin-D and pheophorbide A: Berberis species components that potentiate berberine growth inhibition of resistant Staphylococcus aureus. J. Nat. Prod. 2000, 63, 1146-1149. [CrossRef]

94. Chevalier, J.; Atifi, S.; Eyraud, A.; Mahamoud, A.; Barbe, J.; Pagès, J.-M. New pyridoquinoline derivatives as potential inhibitors of the fluoroquinolone efflux pump in resistant Enterobacter aerogenes strains. J. Med. Chem. 2001, 44, 4023-4026. [CrossRef]

95. Ohene-Agyei, T.; Mowla, R.; Rahman, T.; Venter, H. Phytochemicals increase the antibacterial activity of antibiotics by acting on a drug efflux pump. Microbiologyopen 2014, 3, 885-896. [CrossRef] [PubMed]

96. Zhao, X.; Drlica, K. Reactive oxygen species and the bacterial response to lethal stress. Curr. Opin. Microbiol. 2014, 21, 1-6. [CrossRef] [PubMed]

97. Acker, H.V.; Coenye, T. The role of reactive oxygen species in antibiotic-mediated killing of bacteria. Trends Microbiol. 2017, 25, 456-466. [CrossRef]

98. Dharmaraja, A.T.; Alvala, M.; Sriram, D.; Yogeeswari, P.; Chakrapani, H. Design, synthesis and evaluation of small molecule reactive oxygen species generators as selective Mycobacterium tuberculosis inhibitors. Chem. Commun. 2012, 48, 10325-10327. [CrossRef]

99. Memar, M.Y.; Ghotaslou, R.; Samiei, M.; Adibkia, K. Antimicrobial use of reactive oxygen therapy: Current insights. Infect. Drug Resist. 2018, 11, 567-576. [CrossRef]

100. Singh, A.V.; Jungnickel, H.; Leibrock, L.; Tentschert, J.; Reichardt, P.; Katz, A.; Laux, P.; Luch, A. ToF-SIMS 3D imaging unveils important insights on the cellular microenvironment during biomineralization of gold nanostructures. Sci. Rep. 2020, 10, 261. [CrossRef]

101. Singh, A.V. Commentary on "Peptide-conjugated nanoparticles as targeted anti-angiogenesis therapeutic and diagnostic in Cancer" by Shaker, A. Mousa, Pharmaceutical Research Institute, Albany College of Pharmacy and Health Sciences, Rensselaer, NY 12144, United States-Peptide-Conjugated Nanoparticles for Multimodal Nanomedicine. Curr. Med. Chem. 2020, 27, 2927-2928. [PubMed]

102. Bush, N.G.; Evans-Roberts, K.; Maxwell, A. DNA topoisomerases. EcoSal Plus 2015, 6, 2. [CrossRef] [PubMed]

103. D’Atanasio, N.; Capezzone de Joannon, A.; Di Sante, L.; Mangano, G.; Ombrato, R.; Vitiello, M.; Bartella, C.; Magarò, G.; Prati, F.; Milanese, C. Antibacterial activity of novel dual bacterial DNA type II topoisomerase inhibitors. PLoS ONE 2020, 15, e0228509. [CrossRef] [PubMed]

104. Karkare, S.; Chung, T.T.; Collin, F.; Mitchenall, L.A.; McKay, A.R.; Greive, S.J.; Meyer, J.J.; Lall, N.; Maxwell, A. The naphthoquinone diospyrin is an inhibitor of DNA gyrase with a novel mechanism of action. J. Biol. Chem. 2013, 288, 5149-5156. [CrossRef] [PubMed]

105. Mollaei, S.; Khanehbarndaz, O.; Gerami-Khashal, Z.; Ebadi, M. Molecular identification and phytochemical screening of endophytic fungi isolated from Lithospermum officinale L. roots: A new source of shikonin. Phytochemistry 2019, 168, 112116. [CrossRef] [PubMed]

106. Hughes, L.M.; Lanteri, C.A.; O’Neil, M.T.; Johnson, J.D.; Gribble, G.W.; Trumpower, B.L. Design of anti-parasitic and anti-fungal hydroxy-naphthoquinones that are less susceptible to drug resistance. Mol. Biochem. Parasitol. 2011, 177, 12-19. [CrossRef] [PubMed]

107. Lu, X.; Altharawi, A.; Gut, J.; Rosenthal, P.J.; Long, T.E. 1,4-Naphthoquinone cations as antiplasmodial agents: Hydroxy, acyloxy-, and alkoxy-substituted analogues. ACS Med. Chem. Lett. 2012, 3, 1029-1033. [CrossRef] [PubMed]

108. Moreira, D.R.M.; de Sá, M.S.; Macedo, T.S.; Menezes, M.N.; Reys, J.R.M.; Santana, A.E.G.; Silva, T.L.; Maia, G.L.A.; Filho, J.M.B.; de Amorim Camara, C.; et al. Evaluation of naphthoquinones identified the acetylated isolapachol as a potent and selective antiplasmodium agent. J. Enzym. Inhib. Med. Chem. 2015, 30, 615-621. [CrossRef] [PubMed] 